\title{
Modified carbon-containing electrodes in stripping voltammetry of metals
}

\author{
Part I. Glassy carbon and carbon paste electrodes
}

\author{
Natalya Yu. Stozhko - Natalya A. Malakhova • \\ Mikhail V. Fyodorov $\cdot$ Khiena Z. Brainina
}

Received: 19 October 2007 / Revised: 21 October 2007 / Accepted: 21 October 2007 / Published online: 16 January 2008

(C) The Author(s) 2007

\begin{abstract}
Papers dealing with modified electrodes made of carbon materials and composites for use in stripping voltammetry of metals have been reviewed. The review consists of two parts, of which the first considers applications of modified glassy carbon and carbon paste electrodes, while the second describes diverse modified carbon-containing composite and microscopic electrodes. Information about modifiers, electrode modification methods, conditions, and limits of detection of elements in different materials has been tabulated. The review covers 550 papers published in Russia and abroad between 1990 and the first half of 2007.
\end{abstract}

Keywords Modified electrodes · Glassy carbon . Carbon paste electrodes · Stripping Voltammetry . Metal ions determination

\section{Introduction}

Voltammetry is one of the most universal methods of electroanalytical chemistry, which is widely used as a technique for measurement of concentrations of substances and as a tool for analysis of their properties. The growing number of papers concerned with problems and urgent issues of voltammetry is indicative of the increasing interest among chemists to this method. The general status and future trends of voltammetry and electrochemical sensors are described in the reviews [1-7]. A priority line of its

\footnotetext{
N. Y. Stozhko $(\bowtie) \cdot$ N. A. Malakhova $\cdot$ M. V. Fyodorov $\cdot$

K. Z. Brainina

Ural State University of Economy,

8th March St. 62,

620219 Ekaterinburg, Russia

e-mail: sny@usue.ru
}

development that follows from the analysis of those papers is the creation, the study and the use of new electrodes, electrochemical sensors [8], transducers, and detectors for automated, flow-through, and "field" analysis. This is because the electrochemical signal is formed by processes taking place on the electrode surface. Therefore, the condition of the electrode surface, which depends on the origin, the defect content, and the mechanical inhomogeneity of the material, determines many significant quantitative characteristics of electrochemical measurement systems. Required electrochemical properties of the electrode can be obtained if its surface is modified purposefully. Therefore, the modification and the "molecular design" of the transducer surface and the formation of grafted layers on solid surfaces constitute an actively developing new area of investigation. Problems of the chemical modification of solid surfaces, specific and regular features of the modifier attachment to various solid matrices, and examples of practical applications of chemical sensors (modified electrodes) are overviewed in the papers [9-21].

Over a period of years, the development of the voltammetric method was connected with metal, primarily mercury, electrodes. But mercury is an extremely toxic material. This element presents the first-rate hazard leading to severe poisoning and heavy diseases. For this reason, some countries (USA, Japan, EC) have declared a moratorium on the use of mercury in storage batteries, lamps, thermometers, pesticides, etc. Electrodes made of nontoxic materials also tend to smoothly force out mercury electrodes in electroanalysis. As an alternative to toxic mercury electrodes, electrodes of a nontoxic "dental" amalgam $\left(\mathrm{Ag}_{2} \mathrm{Hg}_{3}\right.$ with the surplus silver; [22, 23]) have been developed and used for measurements of heavy metals. Carbon materials (CMs) possessing some attractive features $[24,25]$ are widely used as mercury-free current-conducting 
electrode materials. Firstly, depending on the CM type, the character of the electrical conduction can change from the metal to the semiconductor conduction suggesting broad potentials for a wide range of capacitive, adsorption, catalytic, and kinetic properties. Secondly, the carbon surface can adsorb a variety of compounds by both the nonspecific physical sorption and the specific chemisorption with a functional coating, which can be formed either under the forced action of reagents or due to the presence of native functional groups resulting from a thermomechanical treatment of the material $[25,26]$. Thirdly, the complexation capacity of carbon materials is higher than that of metals. Fourthly, CMs can form strong covalent bonds with some surface modifiers favoring the development of modified electrodes. Fifthly, the carbon surface is electrochemically inert over a wide interval of potentials. All these features predetermine the use of diverse carbon materials in electroanalysis. Glassy carbon, pyrolytic graphite, carbon glass-ceramics, impregnated graphite, carbon fibers, filaments, cloths, gauzes, and composite materials serve as the electrode material. The properties of CM electrodes, their specific features and drawbacks, and applications in voltammetric measurements of substances are described in the Russian reviews published in 1988 and 1990 [27, 28]. The present overview covers papers published in Russia and abroad since 1990. To narrow the borders of an extensive literature stream on modified carbon-containing electrodes for the 17-year period, the current review has been restricted on a method of analysis and analyte. So, the electrodes used for metal ion determination with SV have been described only. All the papers published over this period can be divided into six main groups depending on the type of the electrode used: glassy carbon (GCE), carbon paste (CPE), carbon-containing composite (CCE), impregnated graphite (IGE), thick-film graphite-containing (TFGE) electrodes, carbon microelectrodes (CME), and their arrays (ACME). As Fig. 1 suggests, GCE is the first with

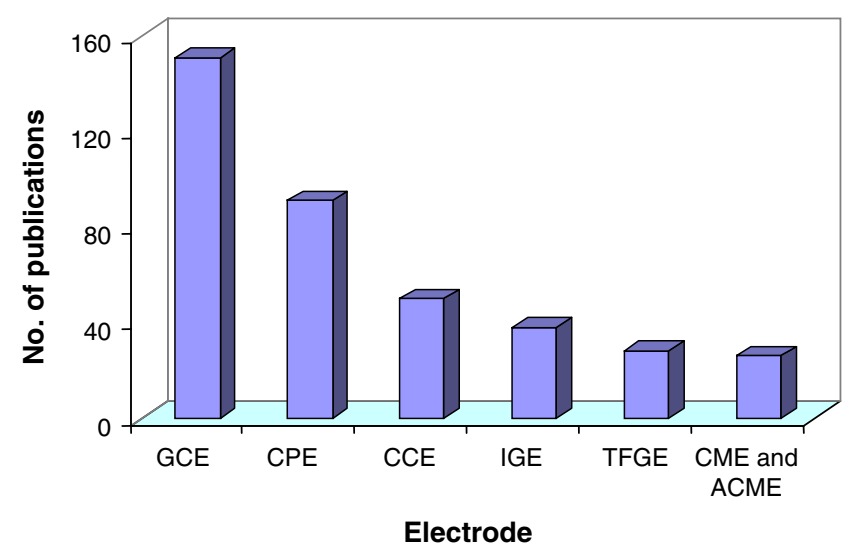

Fig. 1 Representation of papers published in 1990-2005 depending on electrode type described respect to the number of papers published over the 15 years. The minimum number of papers, most of which have appeared recently, are dedicated to TFGE and CME. This is due to the fact that these two groups of the electrodes represent recently emerging and vigorously developing lines of research into the use of carbon-containing electrodes.

\section{Glassy-carbon electrodes}

Glassy carbon is isotropic, is almost gas-tight, has low porosity, is very hard, is a good current conductor, and is stable in many corrosive media [25]. The adsorptivity and the reactivity of glassy carbon are low compared to those of other structured graphite materials having a hexagonal or a rhombohedral lattice. These factors account for the low sensitivity of unmodified glassy-carbon electrodes in analysis [29-34]. The detection limit of elements is reduced by increasing the electrochemical accumulation time (up to $40 \mathrm{~min}$ ) [35-42], using additional accumulation operations, e.g., the ultrasonic extraction [43] or modifying the GCE surface.

Table 1 shows some applications of modified GCE for voltammetric measurements of inorganic ions [44-190]. Methods of the preliminary modification of the surface (ex situ) and the in-analysis modification (in situ) are widely used for the purposeful transformation of the GCE surface properties. These methods are sometimes combined to enhance the selectivity. For example, a film of a metal or a current-conducting polymer is applied to GCE and a selective organic reagent or mercury, gold, or bismuth ions, which co-precipitate with the element to be determined, are added to the solution. GC is a preferable substrate for mercury film electrodes [191]. In this case, the two-layer modification of the surface is realized by the "ex situ/in situ" scheme. On occasion, up to three modified layers each, having its specific application and certain function, are built up on the surface. For example, the layerby-layer modification by a clay mineral, a cation-exchange cross-linked polymer and mercury [156] results in that the GCE surface forms a layer, which possesses cationexchange properties, can form an amalgam, and separates coarse molecules or cations.

The GCE modifiers in common use are metals (mercury [44-68], gold [81-85], cadmium [87], copper [88], lead [89], platinum [90], bismuth [91-96]) and facilitating the precipitation of amalgam-forming and electropositive elements. Organic substances (OS) [107-121], macrocyclic compounds [122-126], polymers [127-131, 157-159, 165166, 169-175], bioactive compounds [186], and nanotubes [187-190] can also serve as GCE modifiers. Different combinations of the modifiers - a metal and OS [70-80, $97-105,106]$, a polymer and a metal $[86,132-147,160$ 


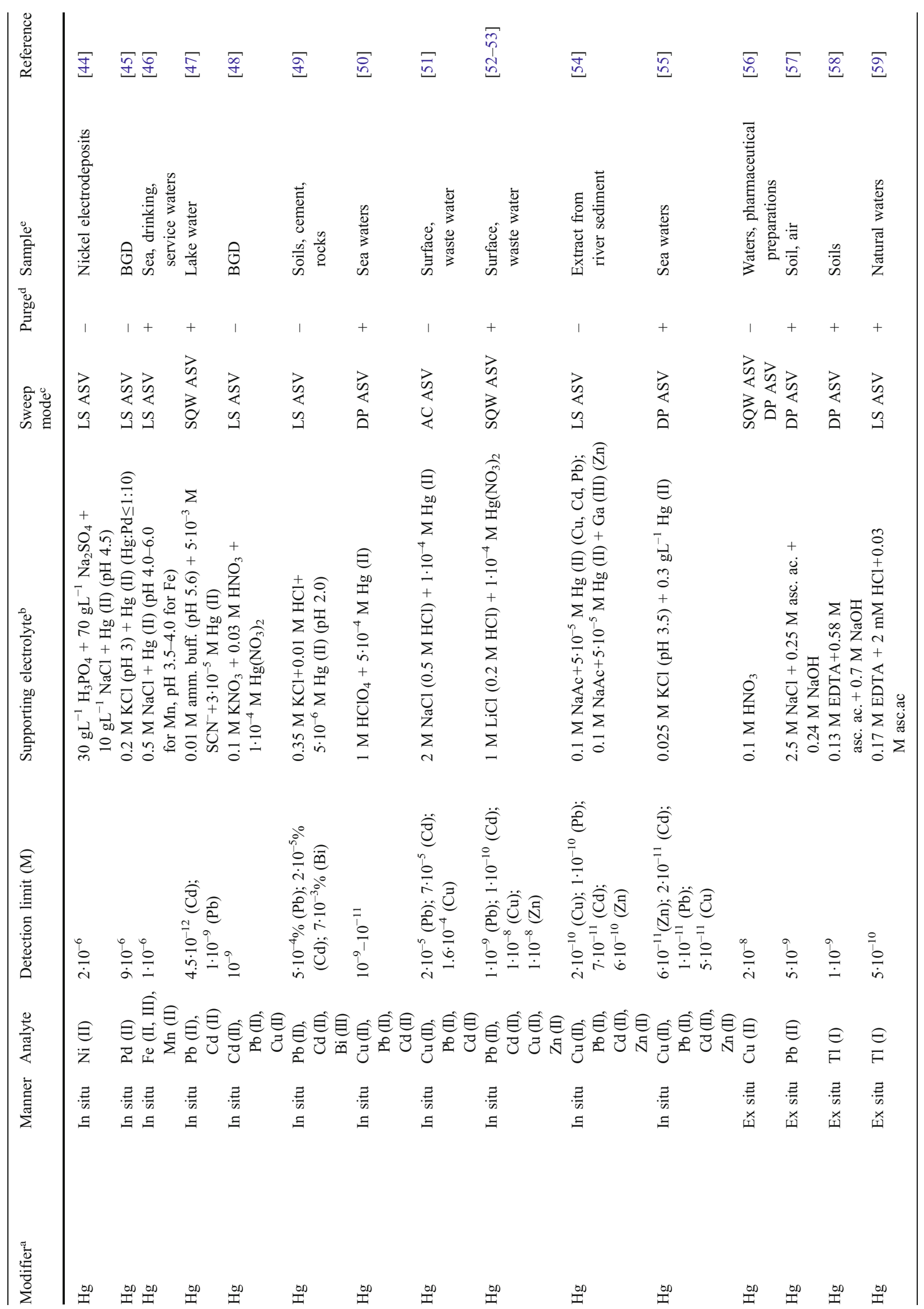




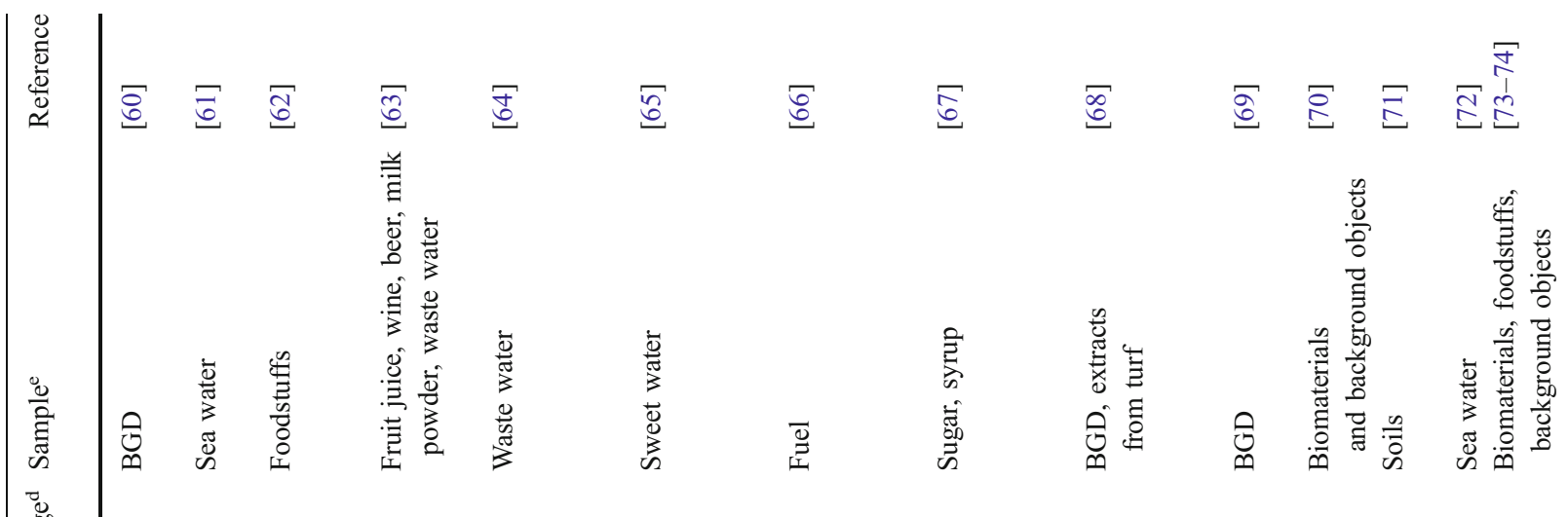

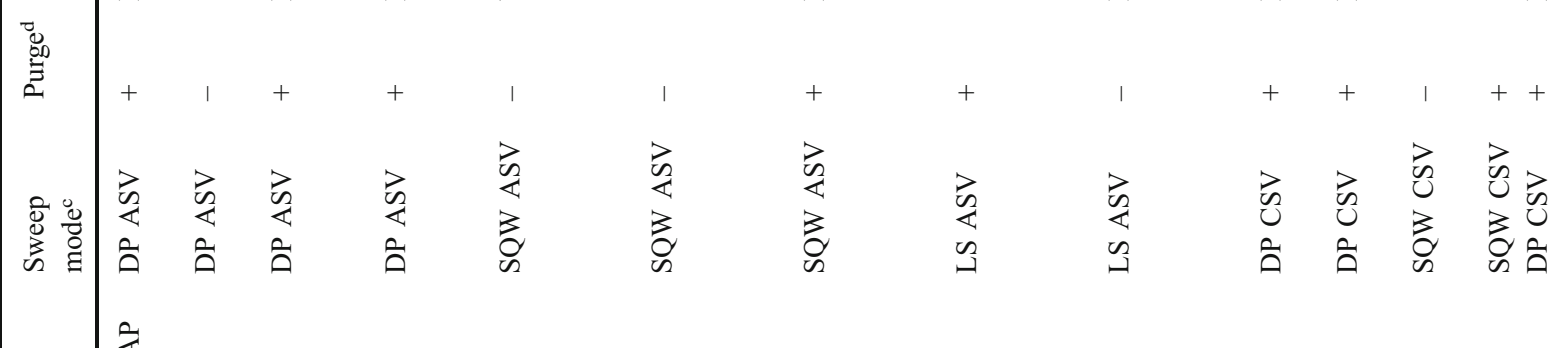

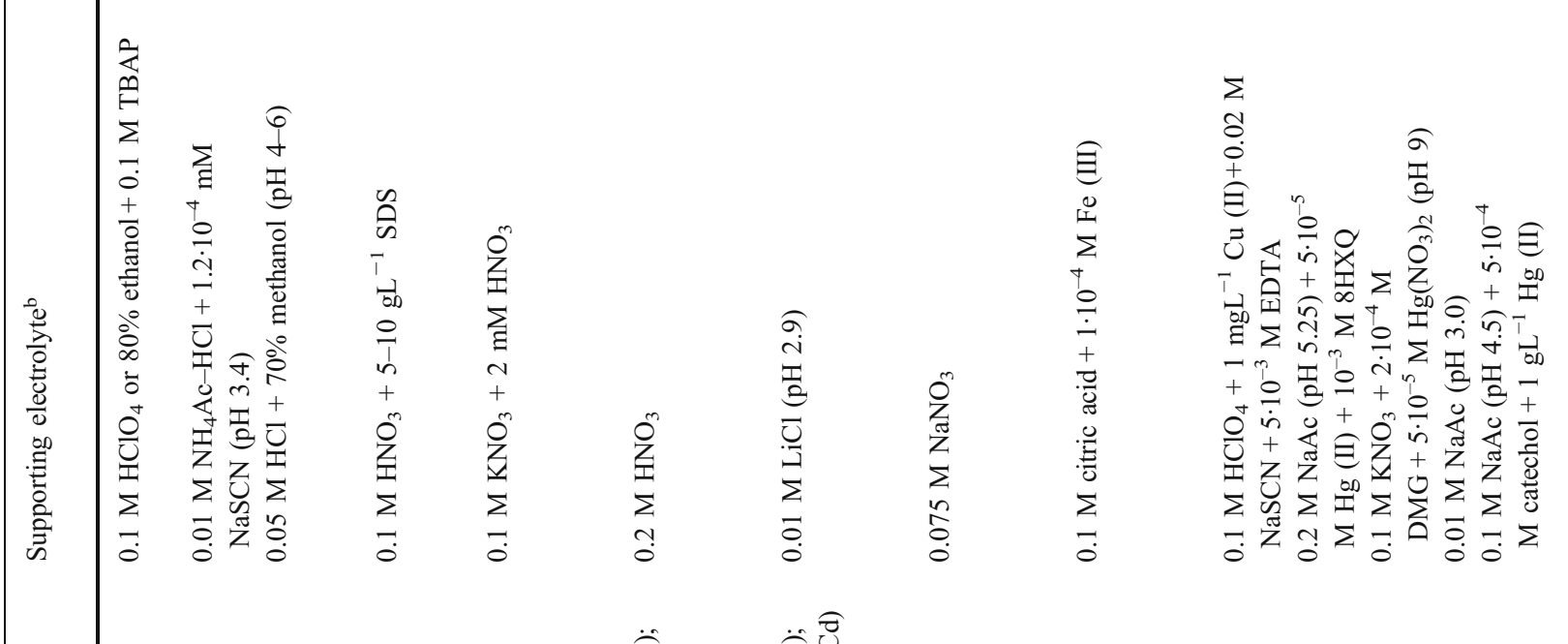

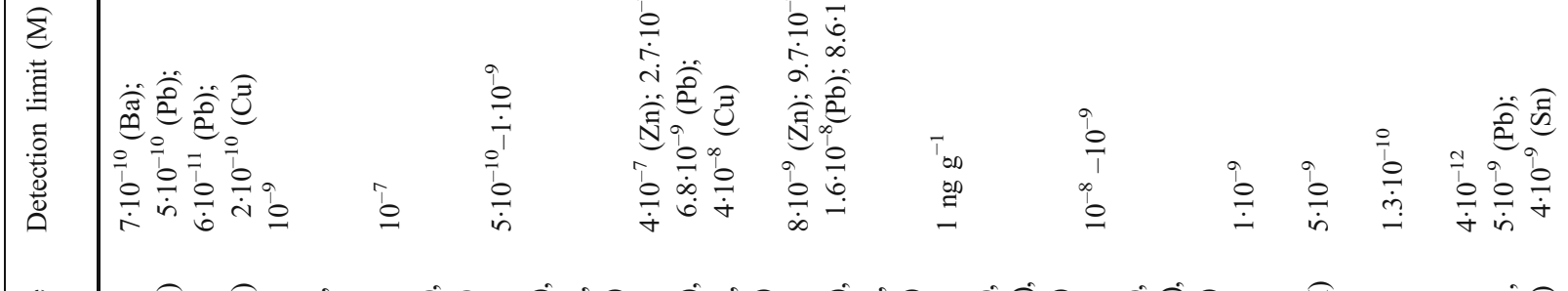

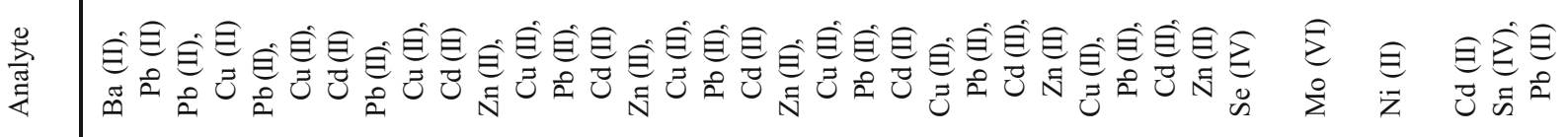

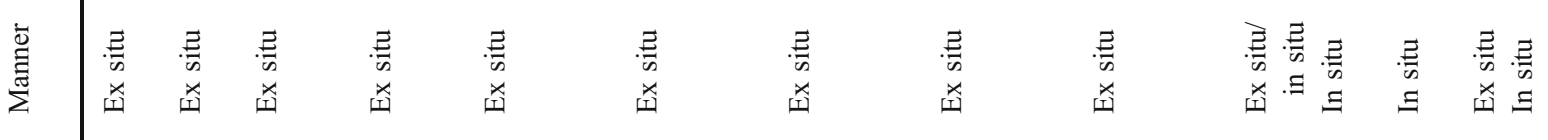

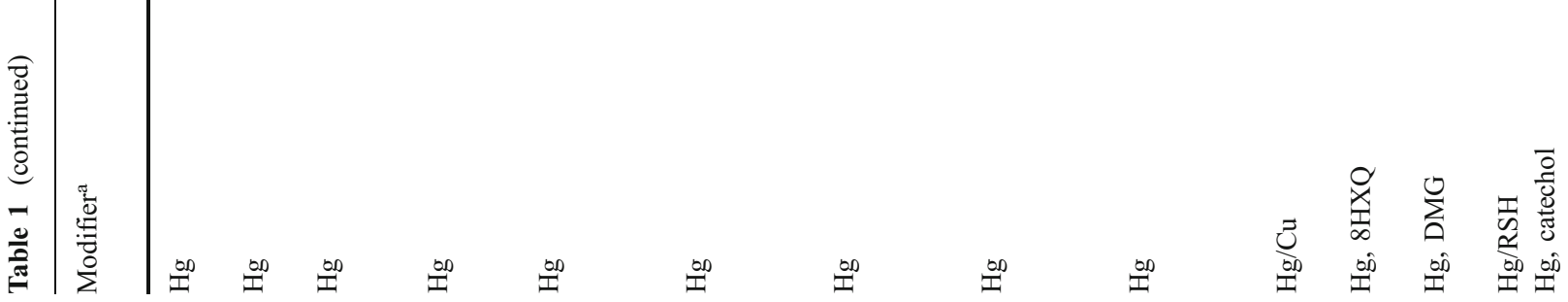




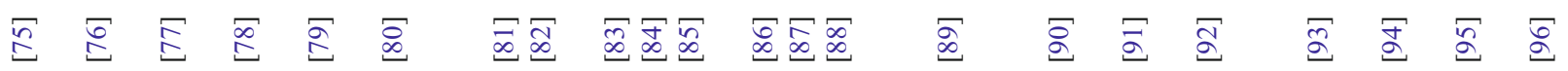

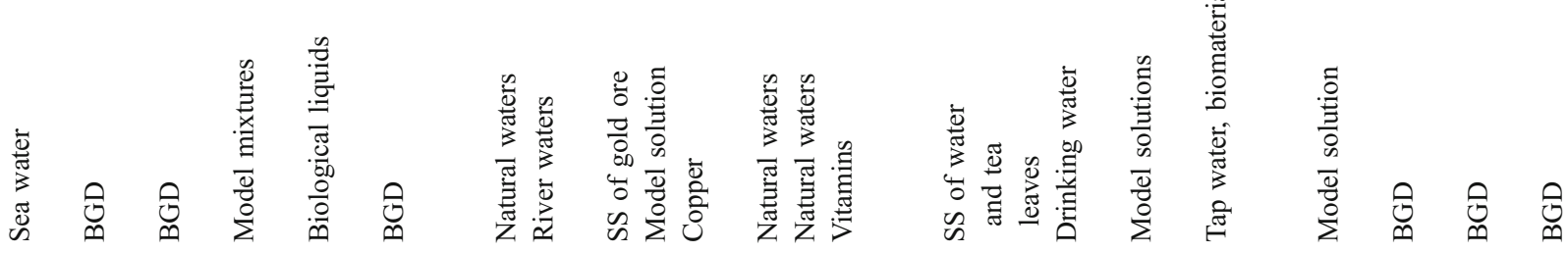

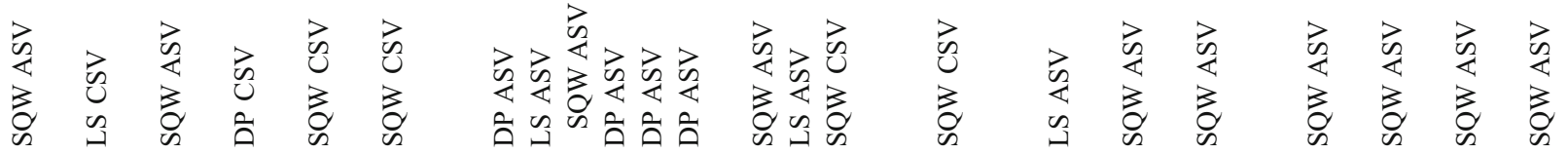

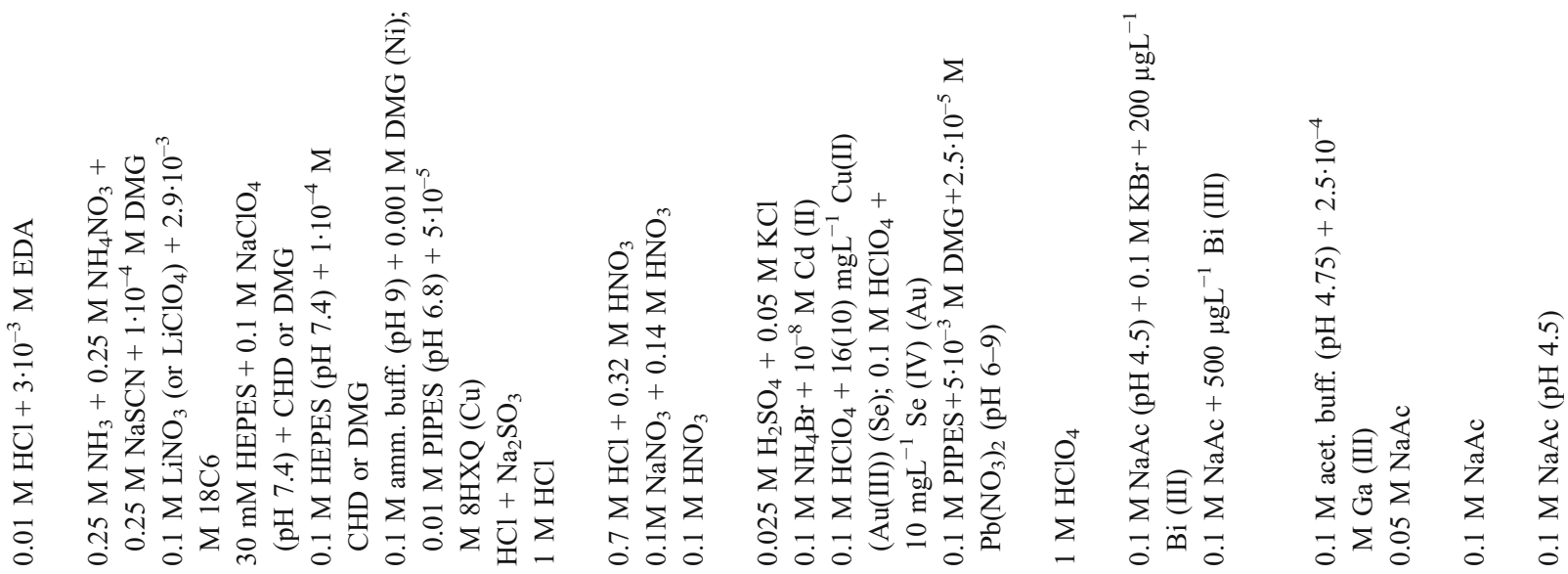

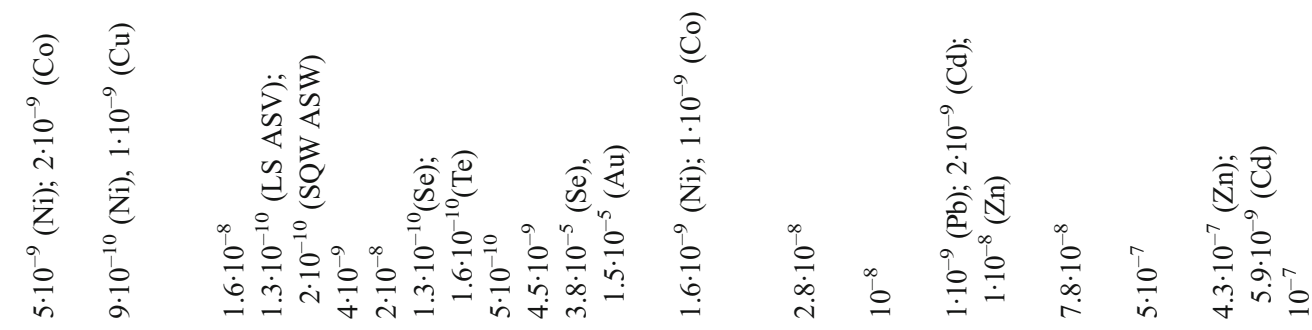

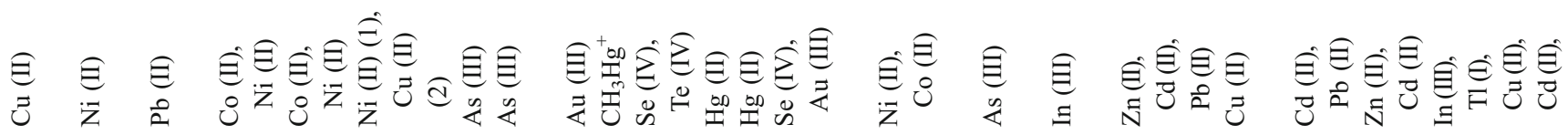

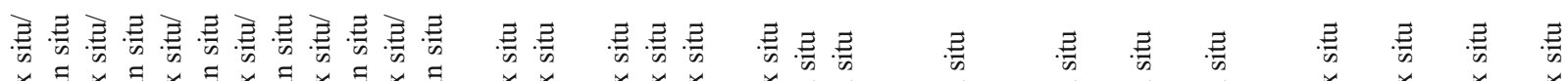

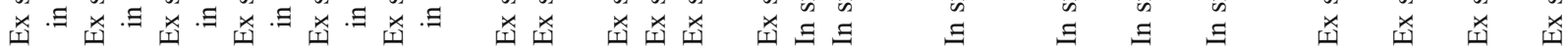

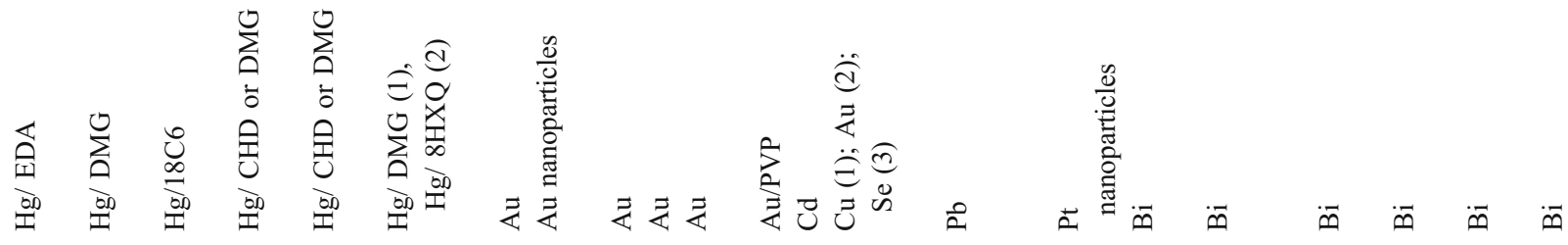




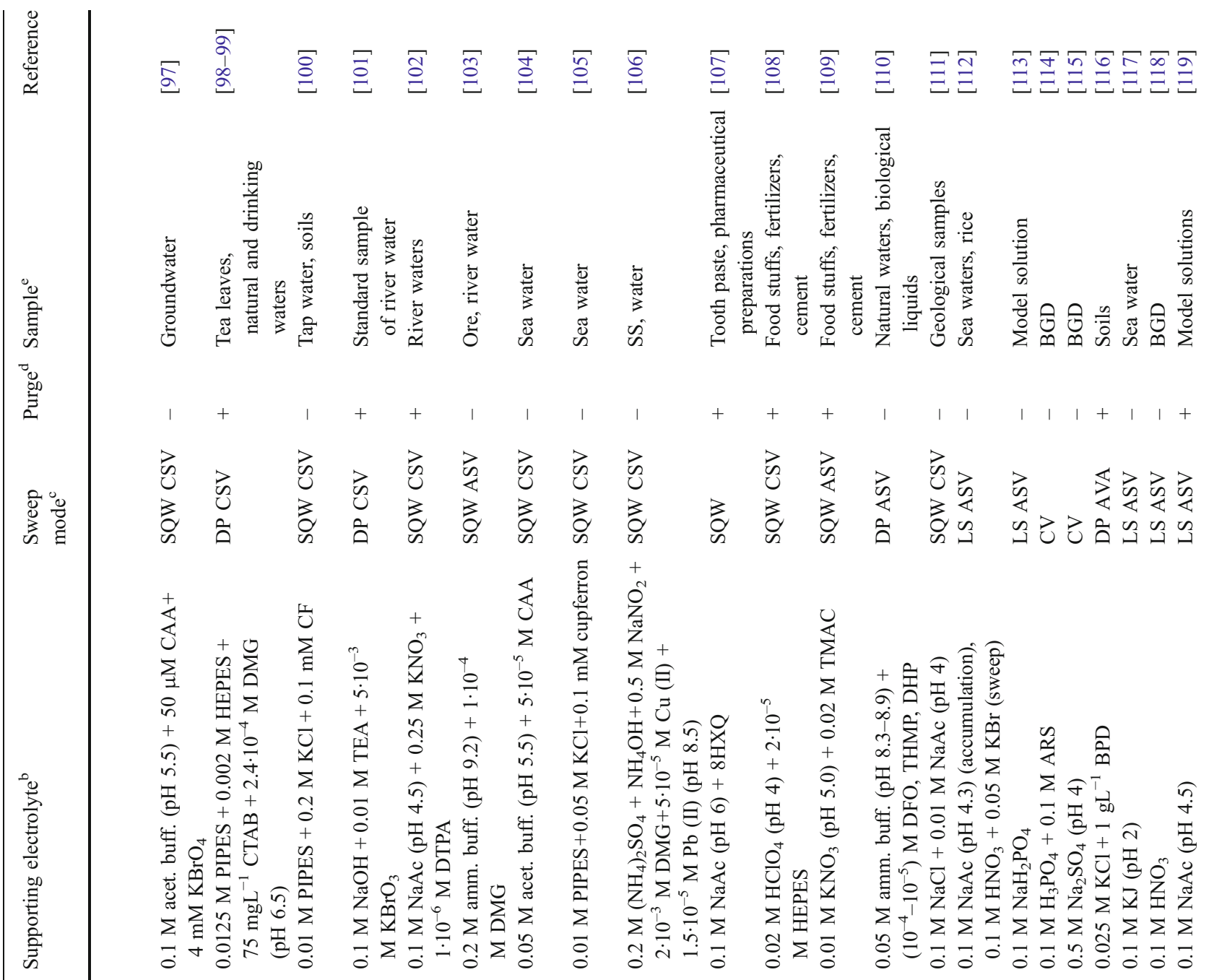

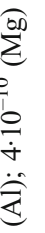

官宅

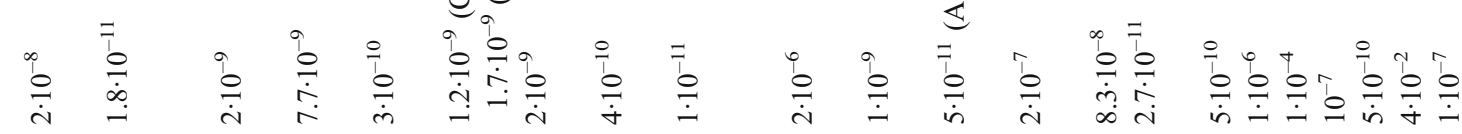

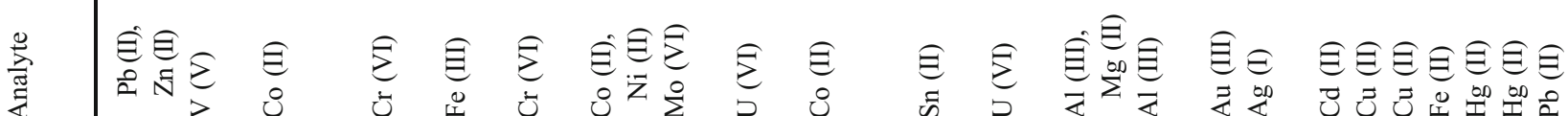

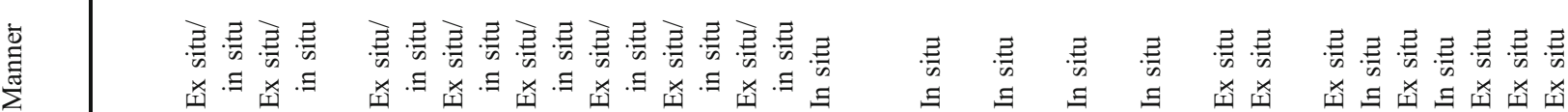

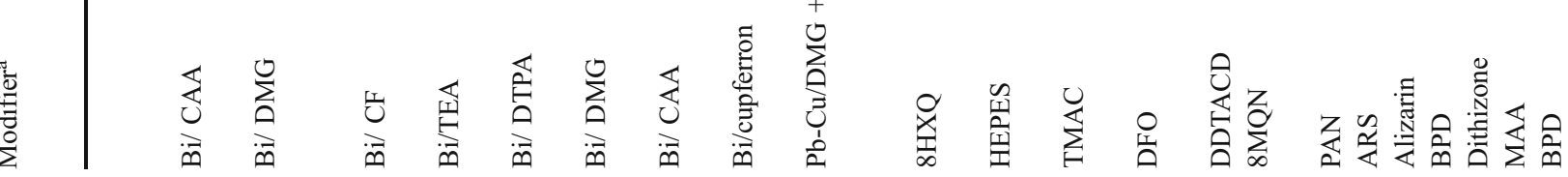




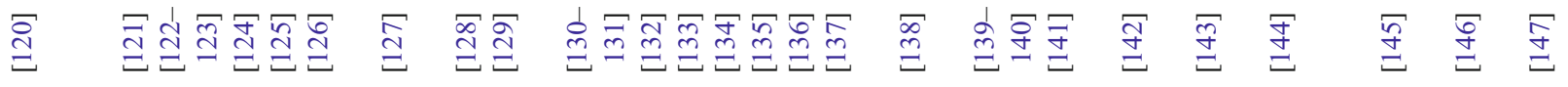

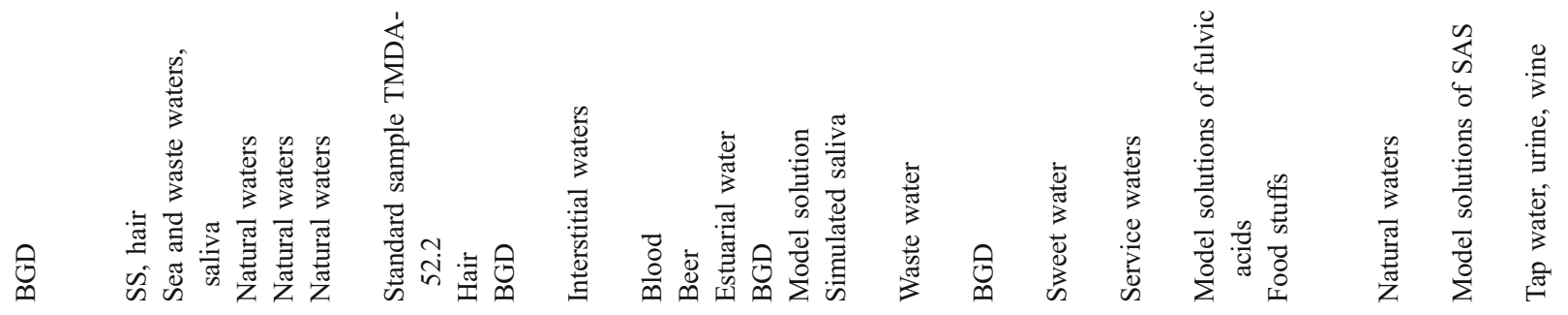

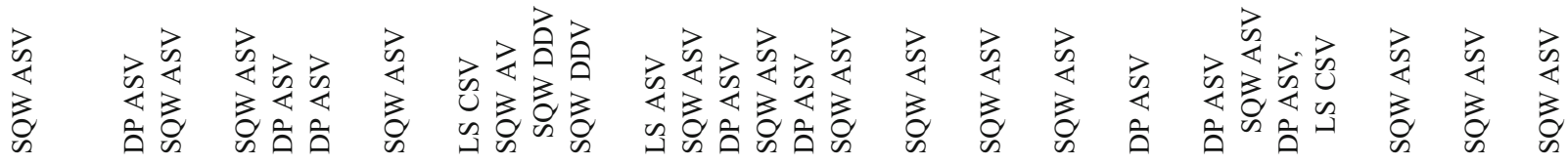

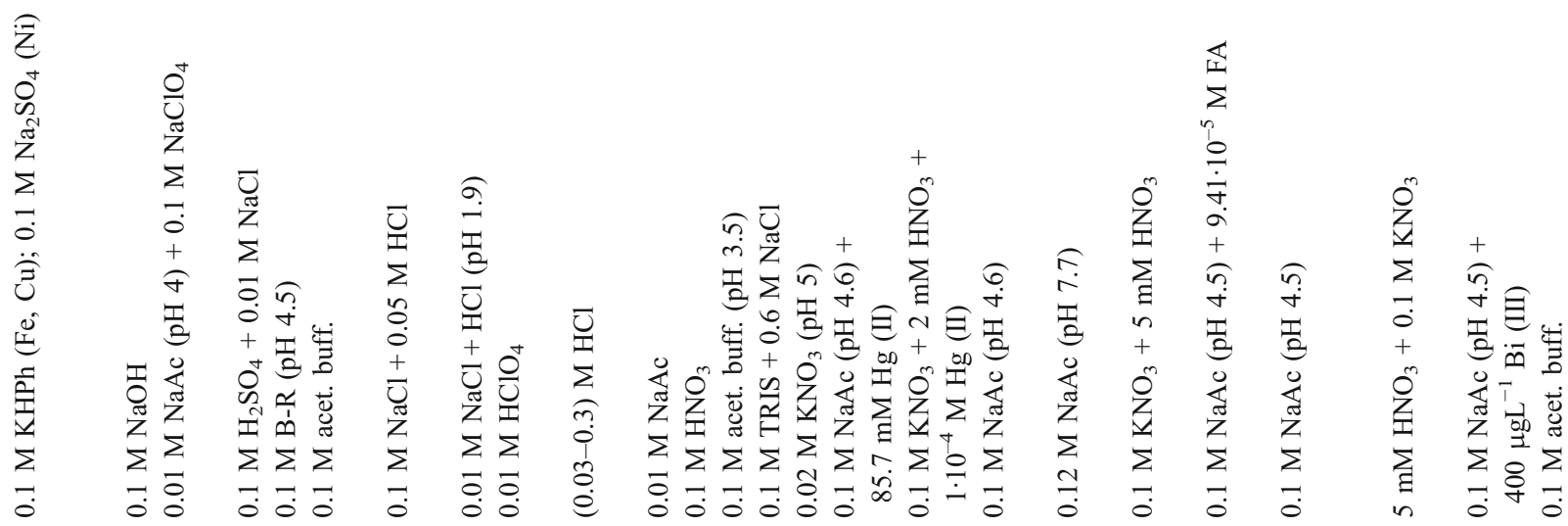

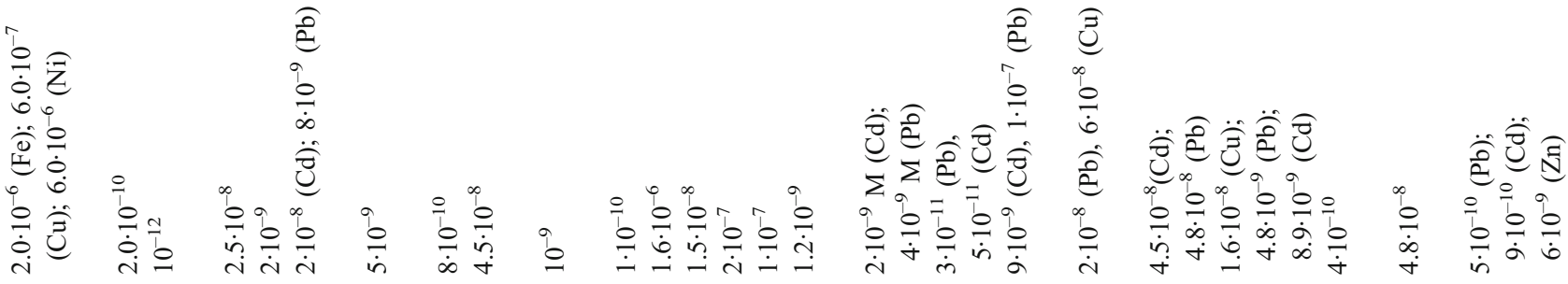

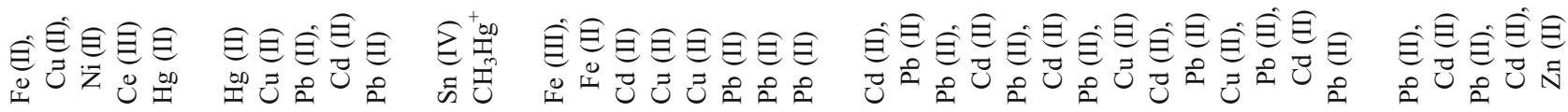

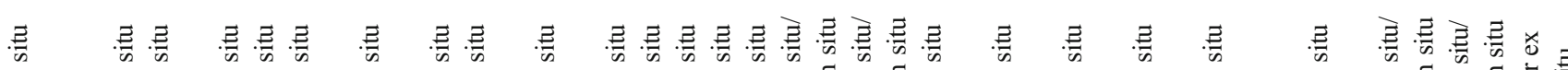

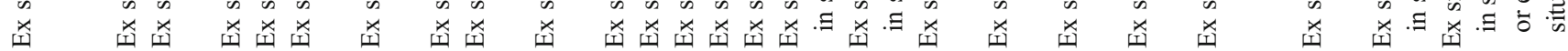

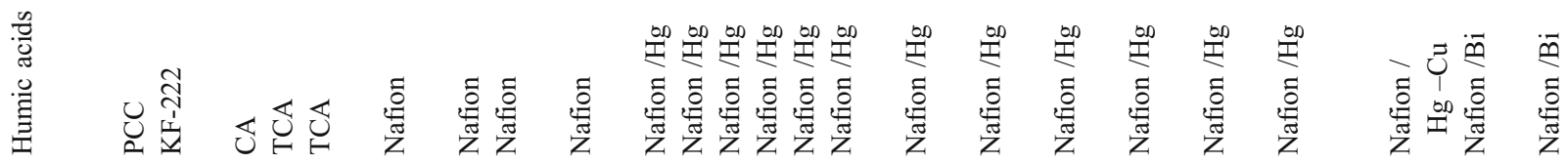




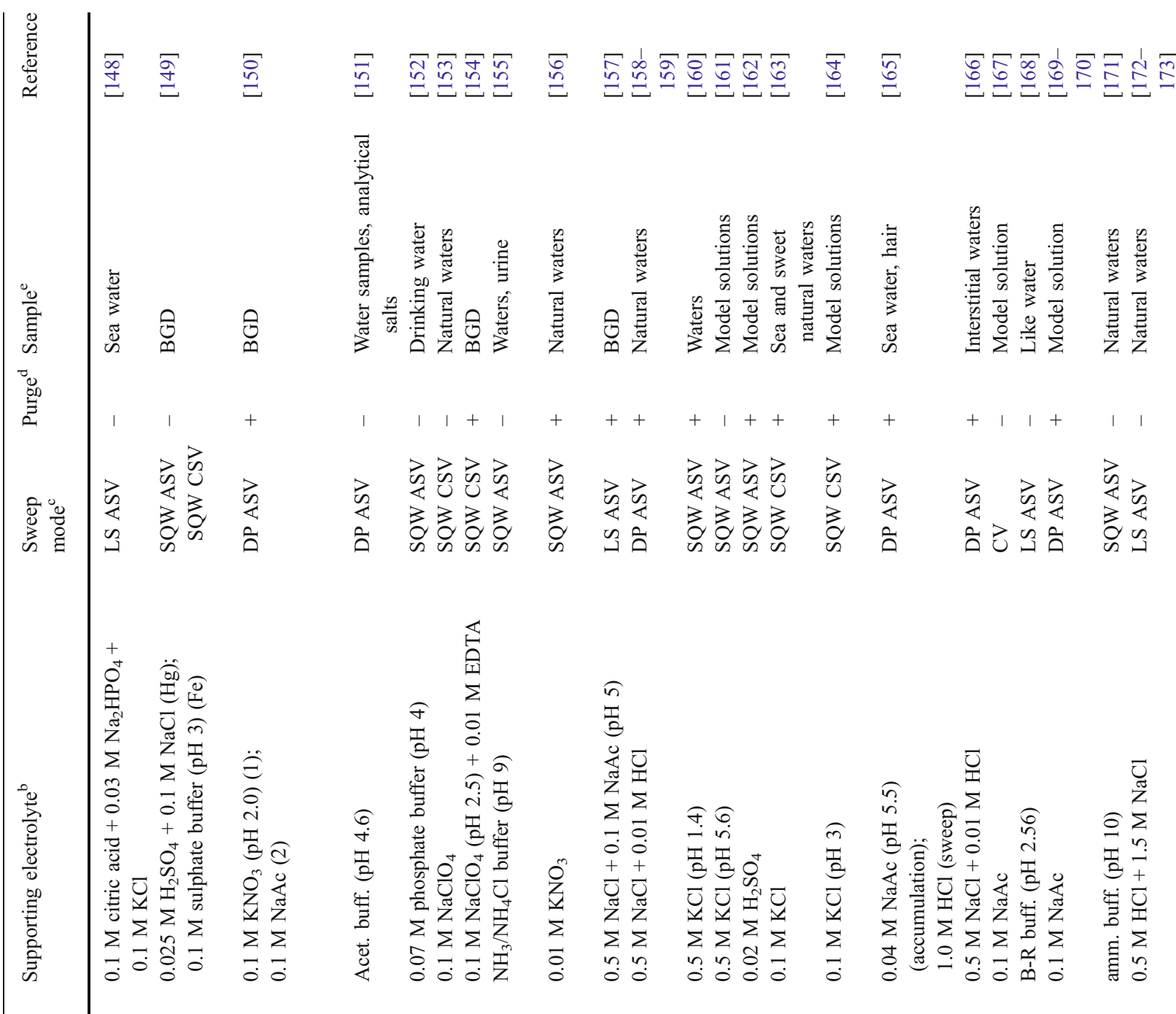

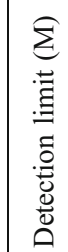

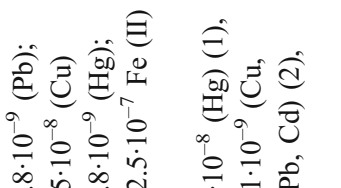

苍

है

$\stackrel{\infty}{\circ}$

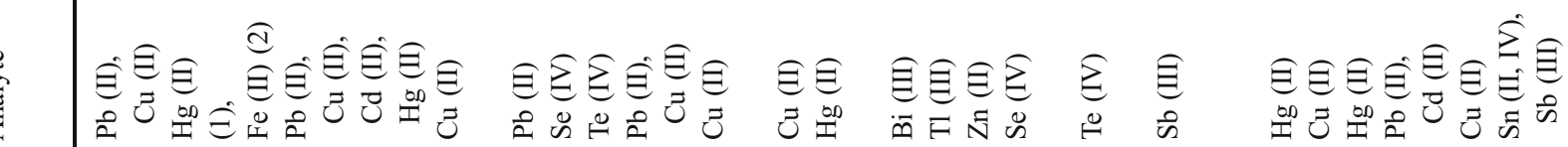

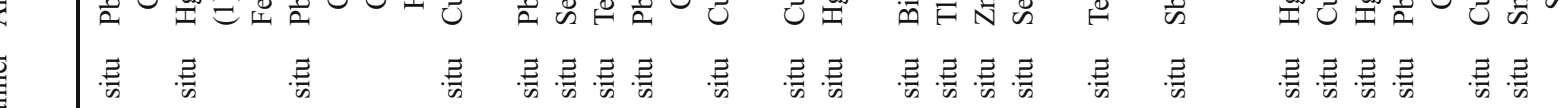

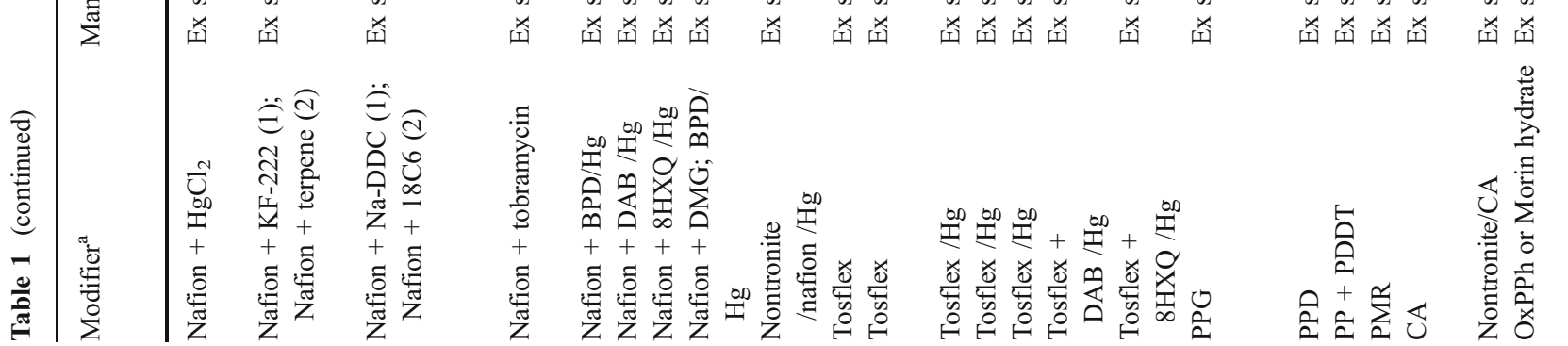




\section{星 喜

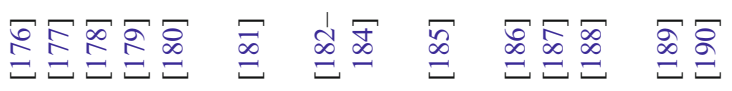

w

离. 首

जि

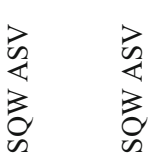

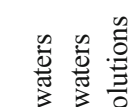

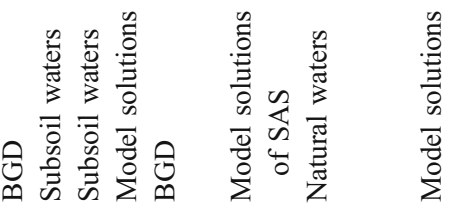

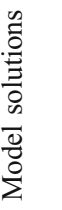

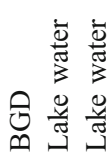

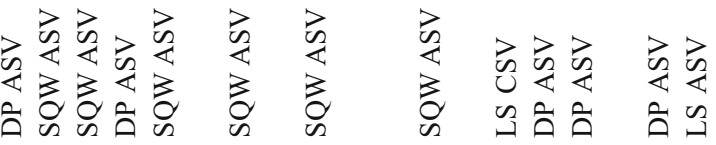

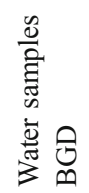

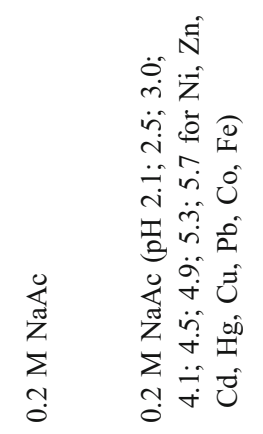

苂

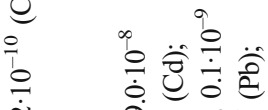

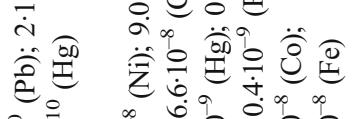

궁

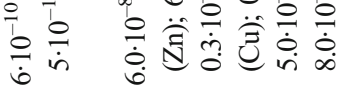

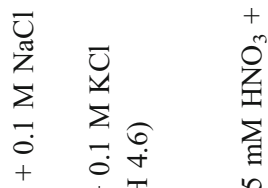

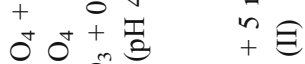

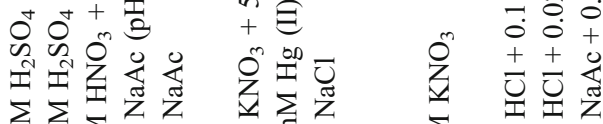

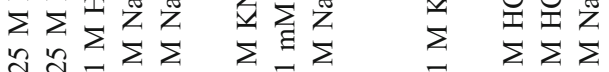

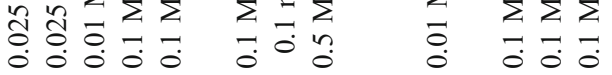

$\overbrace{}^{\infty} \geq$

$\sum_{i} \pi_{0}$

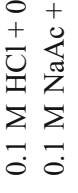

更

글

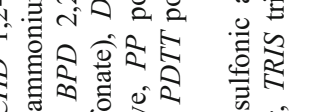

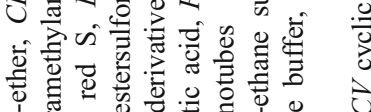

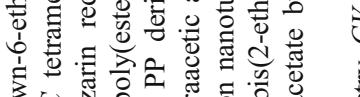

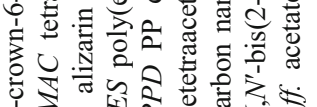

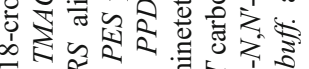

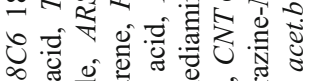

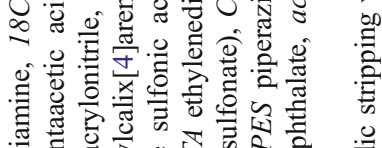

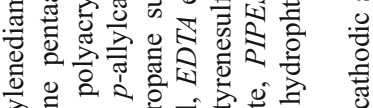

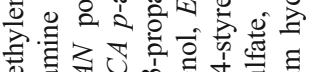

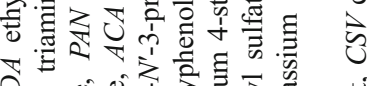

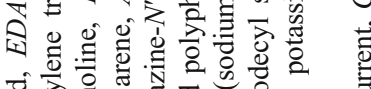

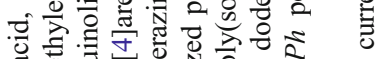

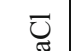

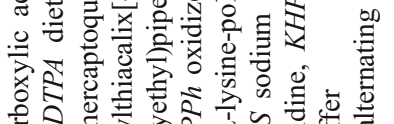

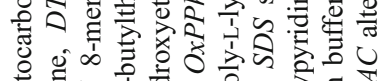

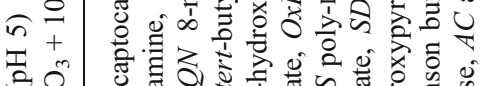
空 这星

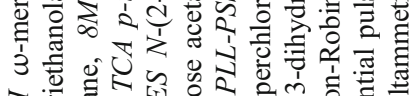

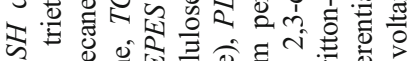

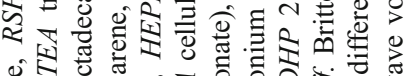

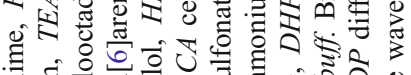

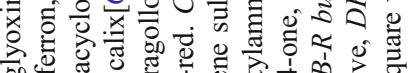

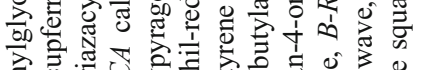

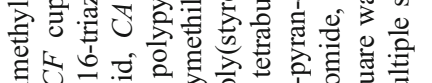

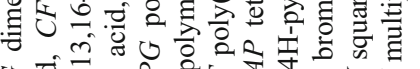

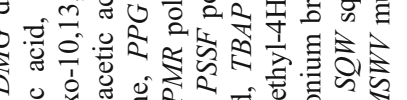

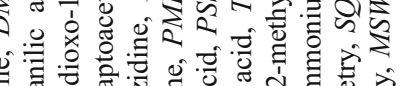

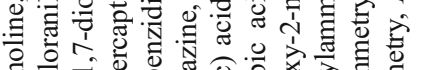

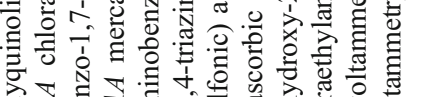

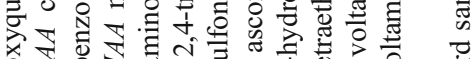

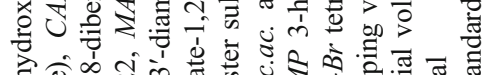

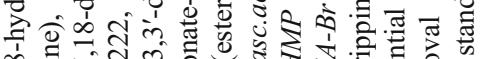
o. 일

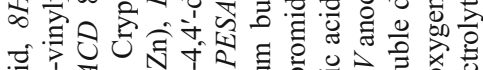

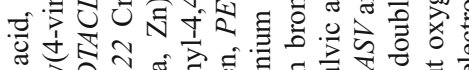

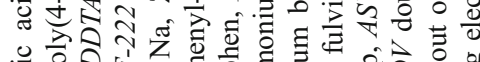

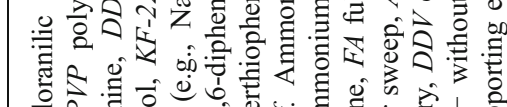

列

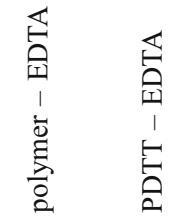

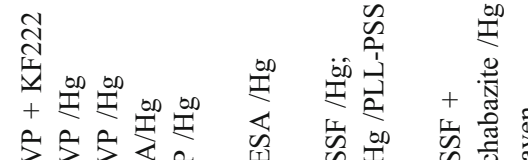
乙 乙空

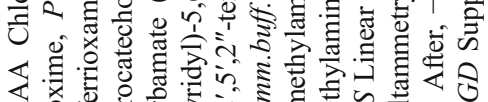

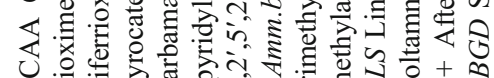


162, 177-184], a polymer and OS [149-151, 167, 174176], a polymer, OS, and a metal [152-155, 163-164, 185] - are used for the GCE surface modification. Watersoluble OS are generally immobilized in situ onto the surface of a pre-activated electrode [70-71, 73-80, 97-110, 114, 116], while low-soluble OS are immobilized ex situ $[72,111-113,115,117-126,149-155,185]$. OS are localized on either the GCE surface [107-126] or the first modifying layer of mercury [70-80], bismuth [97-105] or lead-copper [106].

For a more profound immobilization of the compounds, GCE is pre-polarized at a constant potential of $(1.2 \div 2.0) \mathrm{V}$ $[36,39,41]$ or undergoes multiple (up to 100 ) polarization cycles between 0 and $+1.2 \mathrm{~V}$ in $0.1 \mathrm{M} \mathrm{NaOH}$ [40]. Some investigators think that, in this case, new functional groups appear on the surface [39-41], whereas others are inclined to consider the formation of an oxidized GC film [36]. Still, they are agreed that the anodic polarization radically changes the structure and the composition of the electrode surface, making it possible to fix the modifier or the measured ions on the surface through the ion exchange, the covalent bonding or the electrostatic interaction.

Polymer-coated electrodes constitute a big group of GCE [127-183]. Unique properties of the polymer surface and applications of current-conducting polymers are described in Ivaska [192]. To make a polymer film in the form of a "spin coat", several droplets of the liquid polymer are placed in the working zone, and the electrode is spindled until the polymer film is uniform in thickness. One more method for making of a polymer film (polyaniline, polypyrogallol, polycatechol, etc.) consists in its oxidative electro-polymerization growing from a monomer solution. It was proposed to make superfine $(3,000 \AA)$ polymer films on GCE by an original method of "electrostatic spraying" [169, 170], which involves preparation of a "spray liquid" under the action of a strong electric field. For example, to apply a cellulose acetate film, a strong electric field (the voltage of $14 \mathrm{kV}$ ) was applied to a dielectric mixture, which was composed of cellulose acetate, acetone, and magnesium perchlorate (a porophore). The liquid was charged and was broken into tiny droplets so that a thin, uniform, and homogeneous film covered the electrode. The polymer electrode films generally have a cross-linked structure and act as molecular sieves separating coarse particles, e.g., protein molecules. Moreover, they can function as ion exchangers. For example, nafion and tosflex (fluocarbon polymers) act as a cation exchanger and an anion exchanger, respectively. Some investigators implanted analytical reagents into the structure of current-conducting polymers [148-154, 162-163, 178] providing the enhanced selectivity of the polymer film. The high selectivity to metal ions was achieved [174-175] because polymers with covalently grafted ethylenediaminetetraacetic acid (EDTA) groups were synthesized on GCE. The response selectivity is efficiently improved by the "guest-host" interaction. Properties of crown ethers acting as host molecules for ions of guest metals were used [77, 112, 108-109, 148-149, 176] for measurements of $\mathrm{Au}$ (III), $\mathrm{Hg}$ (II), $\mathrm{Cu}$ (II), $\mathrm{Pb}$ (II), and $\mathrm{Cd}$ (II) ions on electrodes modified by crown-ether adsorption and a nafion film with immobilized macrocycles.

One more method for improvement of the voltammetric selectivity is the use of electrodes with monolayers of organic molecules self-organized on the electrode surface [72, 193-194]. For example, $\omega$-carboxylic acids with hydrocarbon chains of different lengths can arrange themselves to the Langmuir palisade on gold or mercury surfaces. While possessing discrimination properties, functionalized layers can change the transport of depolarizer particles to the electrode surface not only due to different charges, but also due to the hydrophobic effect.

The pioneering studies concerned with the use of nanotube-modified GCE include the research performed by a group of Taiwan investigators [187, 188]. Such electrodes provided sufficiently low detection limits for elements. However, the introduction of these electrodes to the analytical practice requires solving the problem of structural ordering in the nanotube layer which influences the reproducibility of measurement results.

A serious problem in the use of GCE is the degradation of the modified surface showing up as the displacement of the current peak potential of the determined element, the distortion of the peak shape, and the emergence of additional peaks [195]. To make the GCE surface reproducible, it is prepared and cleaned by a great variety of methods such as mechanical polishing [108], treatment with reagents [76], electrochemical treatment by polarization at high anode potentials [36, 186], and exposure to microwaves or ultrasound [29, 40, 131]. Mechanical polishing of the surface with abrasive diamond or $\mathrm{Al}_{2} \mathrm{O}_{3}$ powders or special polish cloths is in most common use. This surface treatment method is not only laborious and time-consuming, but what is the worst does not guarantee that the surface properties will be reproducible. This problem was attacked by development of automatic devices for cleaning of the solid electrode surface [116], but they have been used on a narrow scale because of their complexity and high cost. The original approach has been used [190] to modify GC with glassy carbon spheres covered by nanoparticles of precious metals and multiwalled nanotubes.

\section{Carbon-paste electrodes}

In 1958, Adams described a new type of the carbon-paste electrode (CPE) for voltammetry. This electrode was 


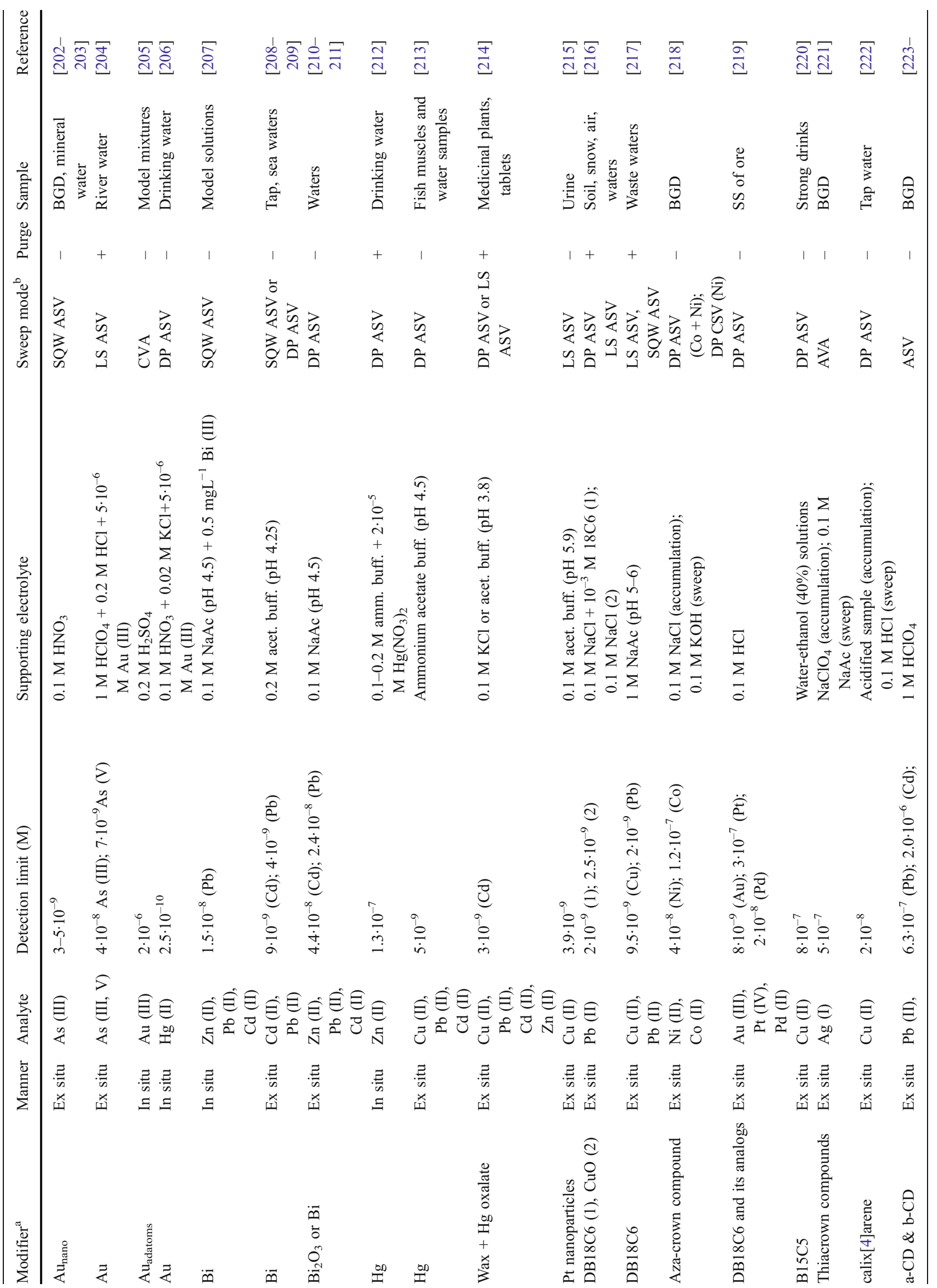




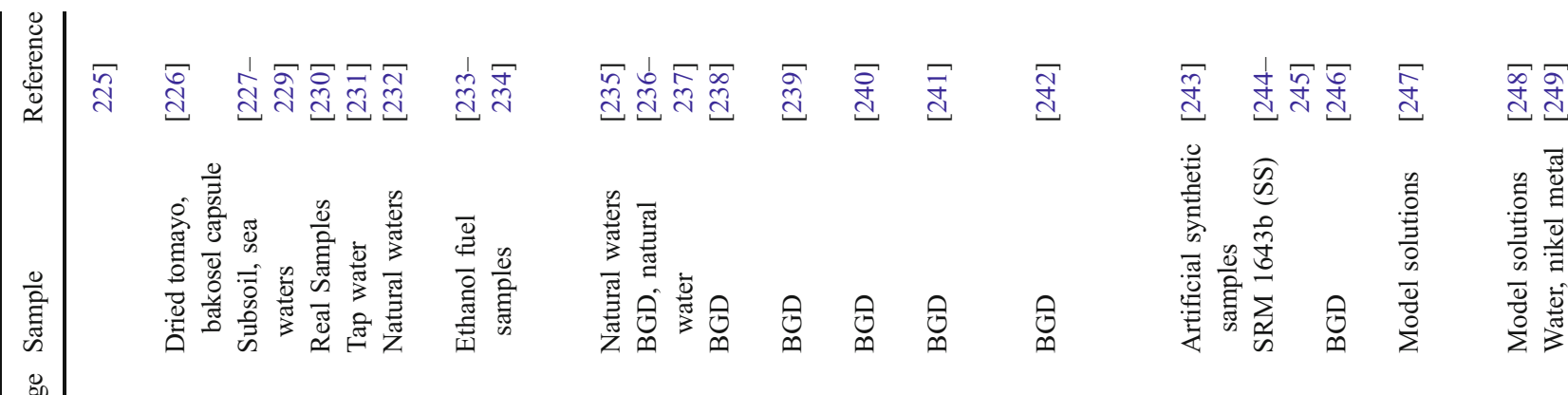

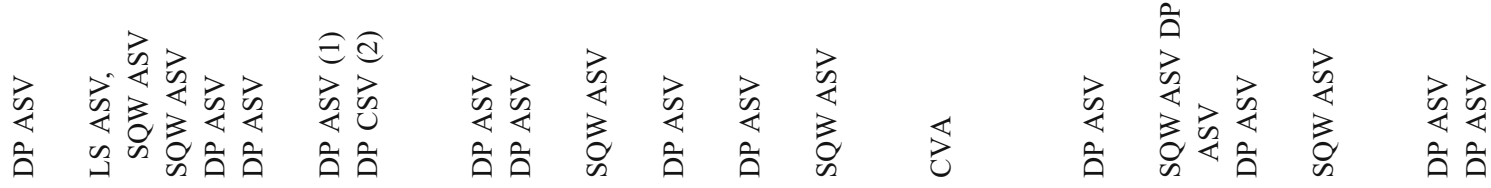

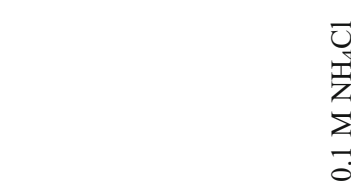
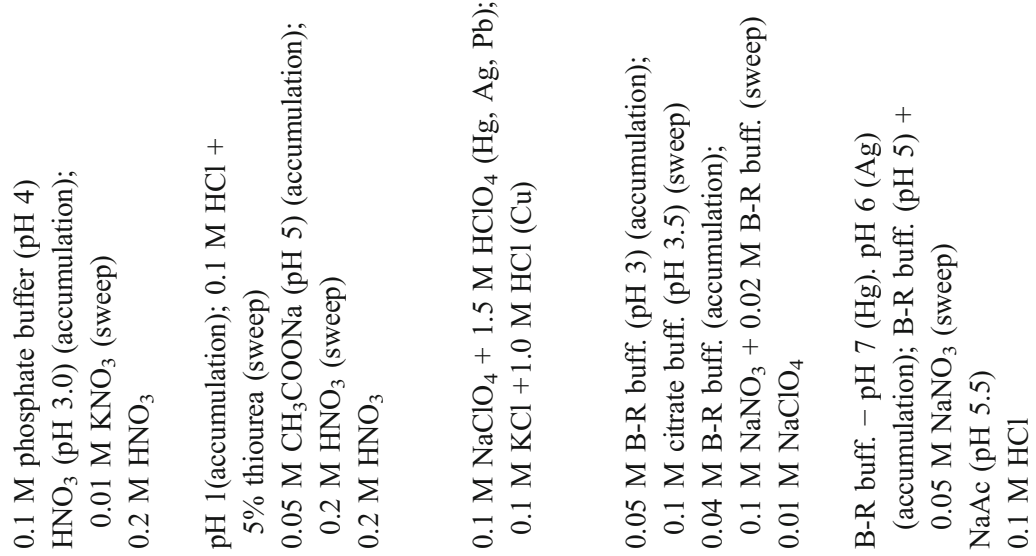

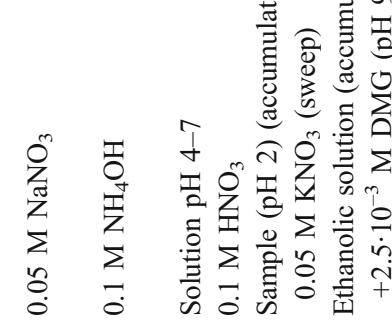

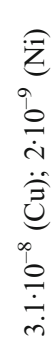

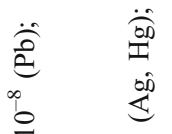

已.

$\stackrel{\infty}{\circ} \stackrel{0}{1}$

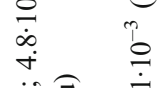

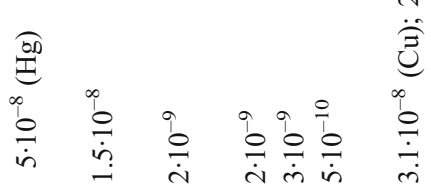

昰

$\dot{\bar{m}} \dot{\ddot{\sigma}}$

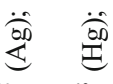

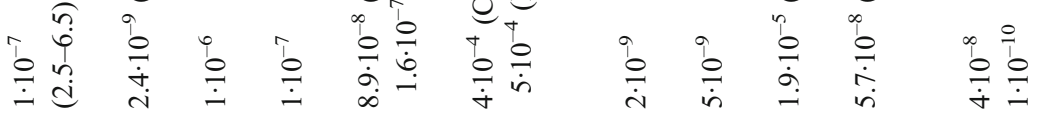

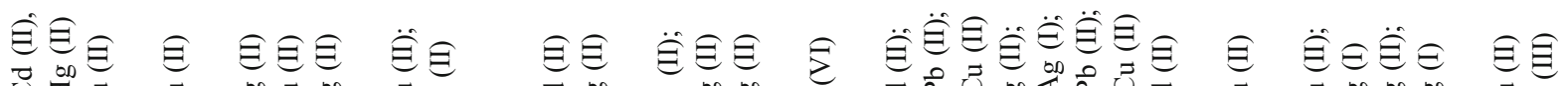

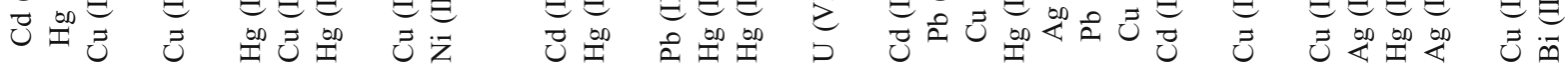
喜帝

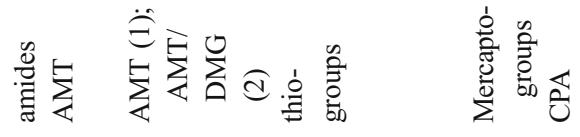

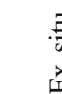

\section{䒺}

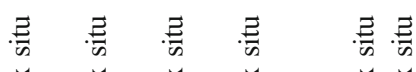
肴肴肴肴肴肴

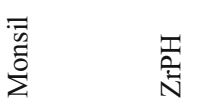

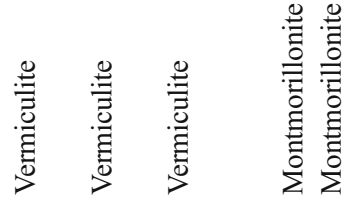




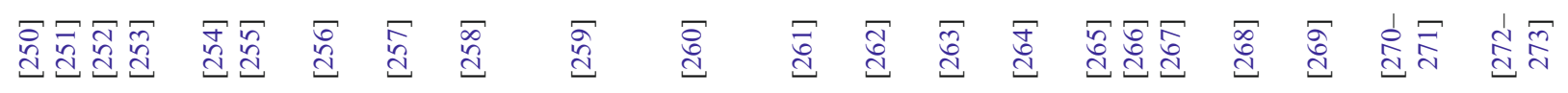

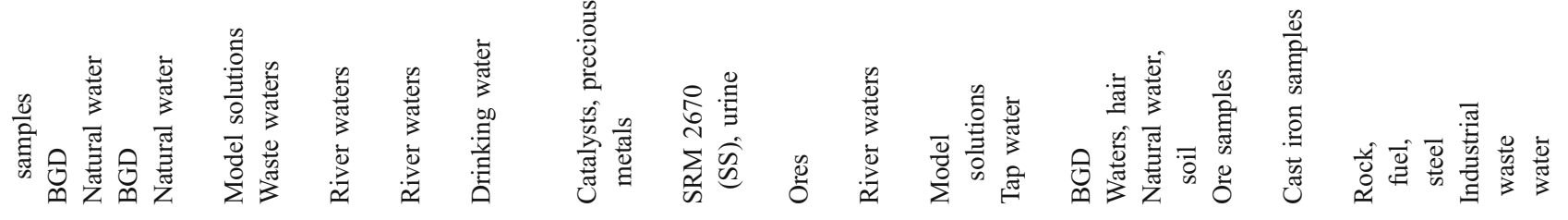

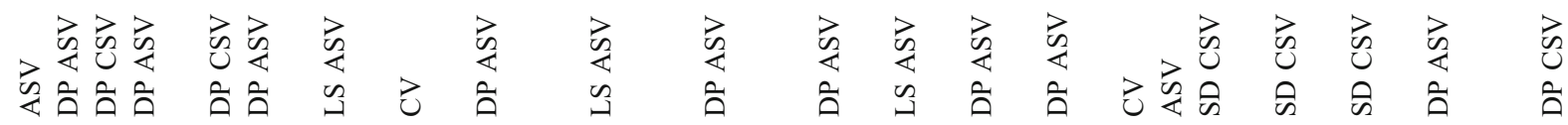

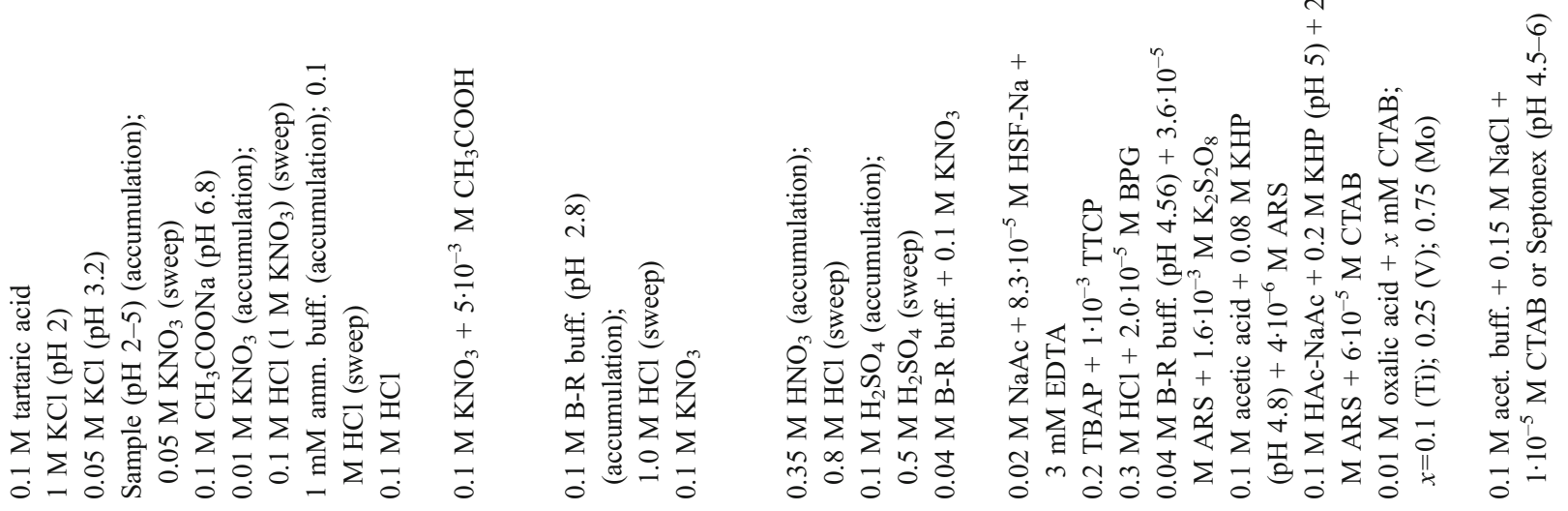

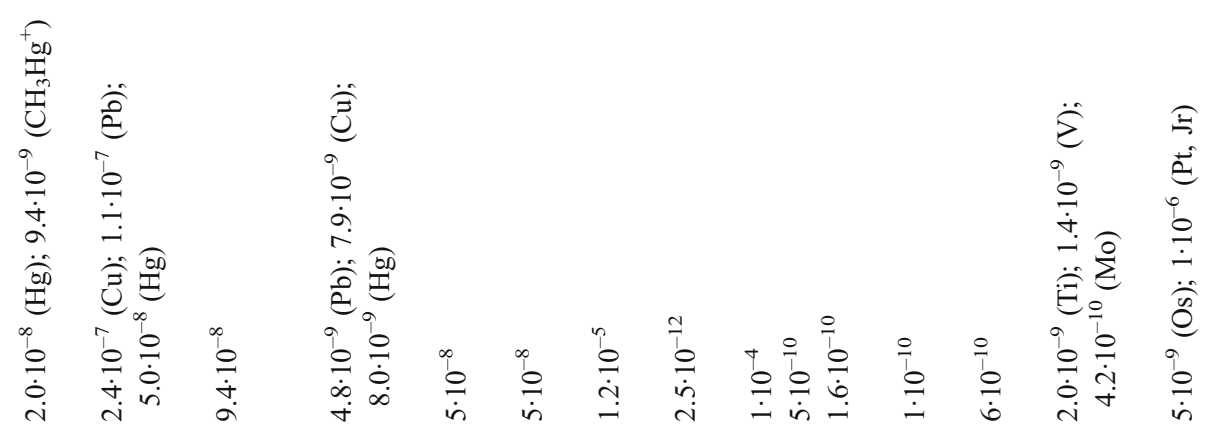

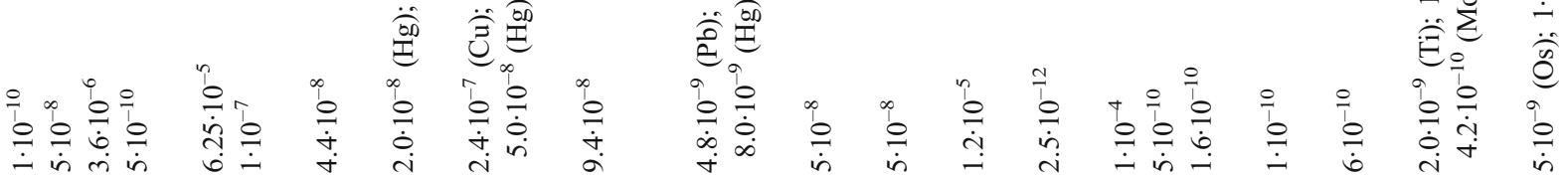

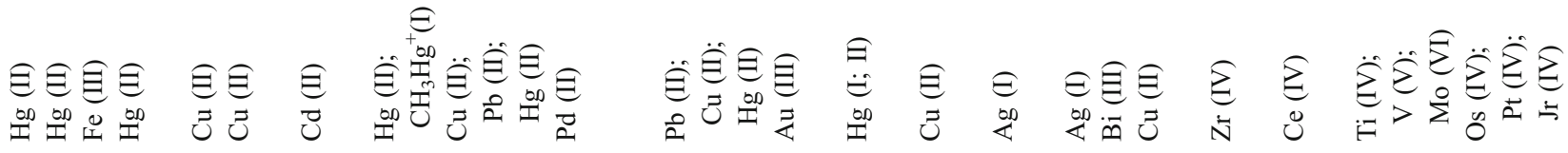

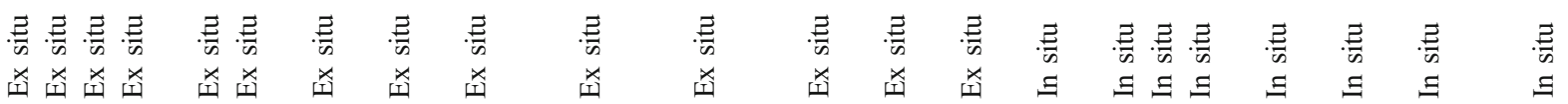

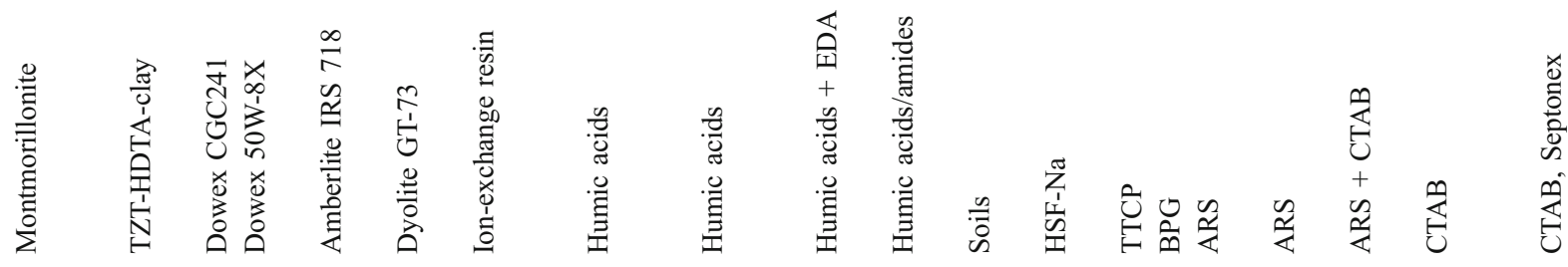




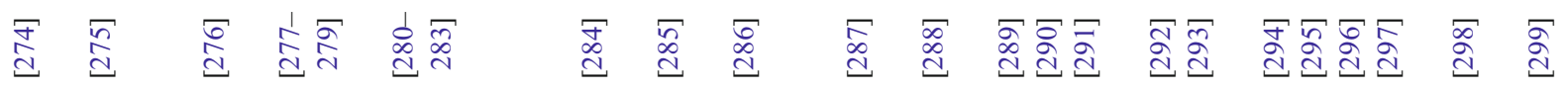

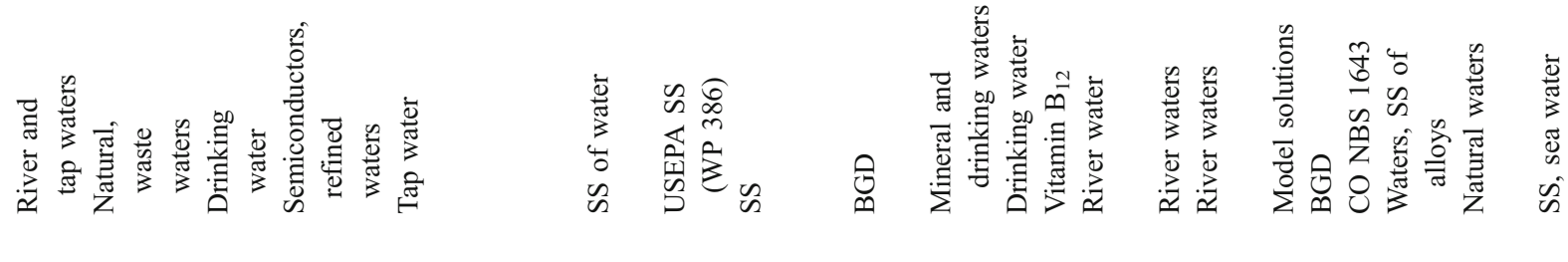

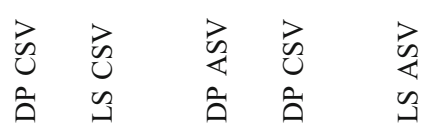

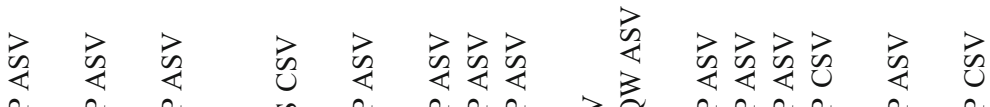

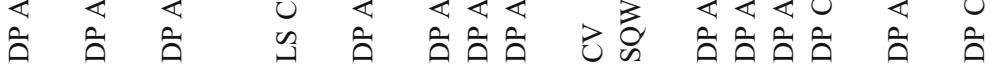

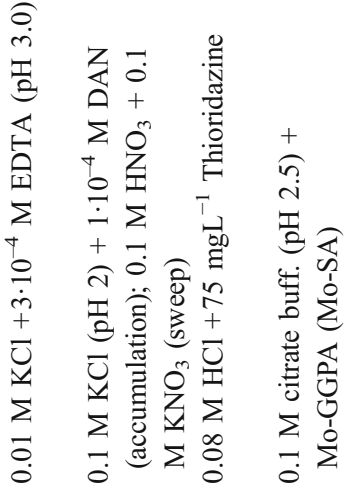

폴 吾

¿े:

กำ

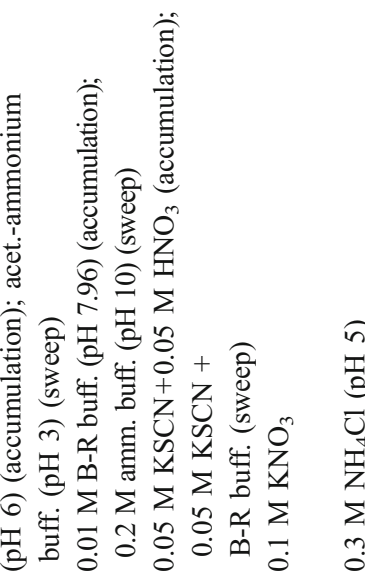

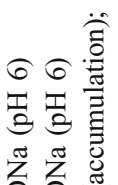

言

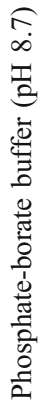

$\vec{\theta}$

突若

$\frac{2}{0}$

8

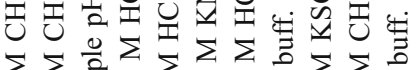

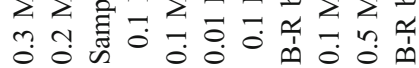

告

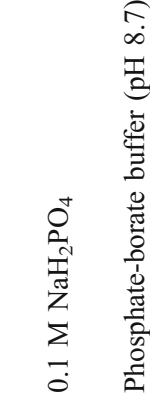

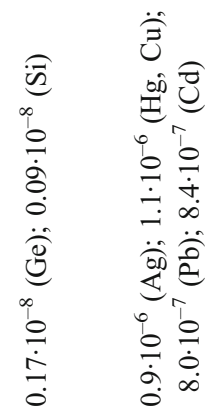

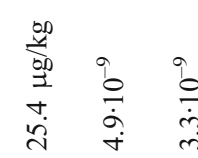

$\hat{O}_{1}$

छ

$\stackrel{\circ}{\dot{\gamma}} \in$

高

i)

일

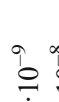

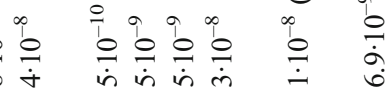

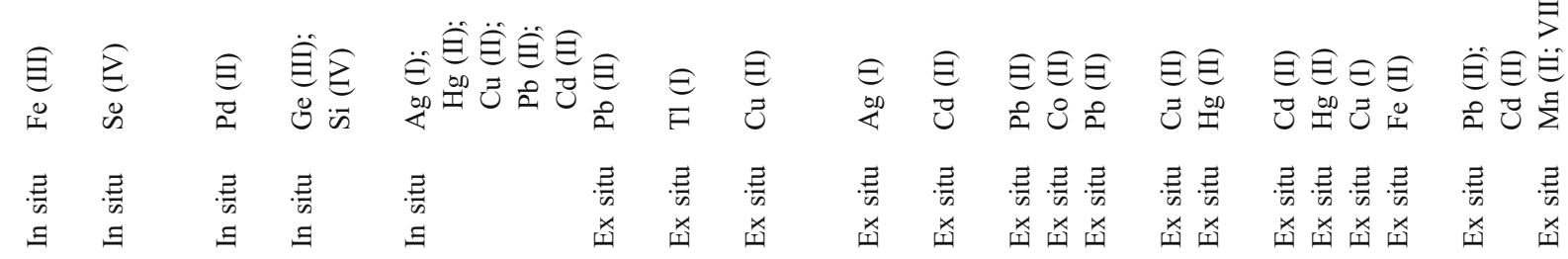

号

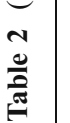

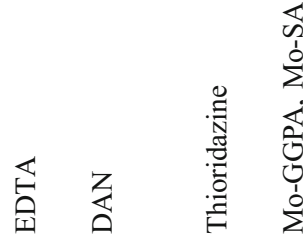

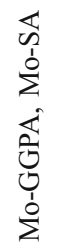

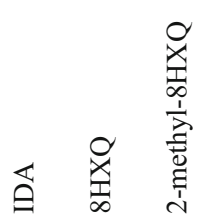

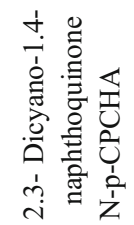

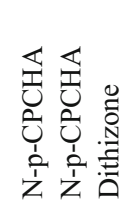

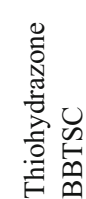

.

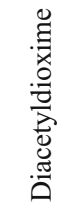




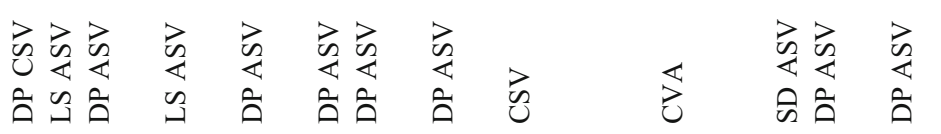
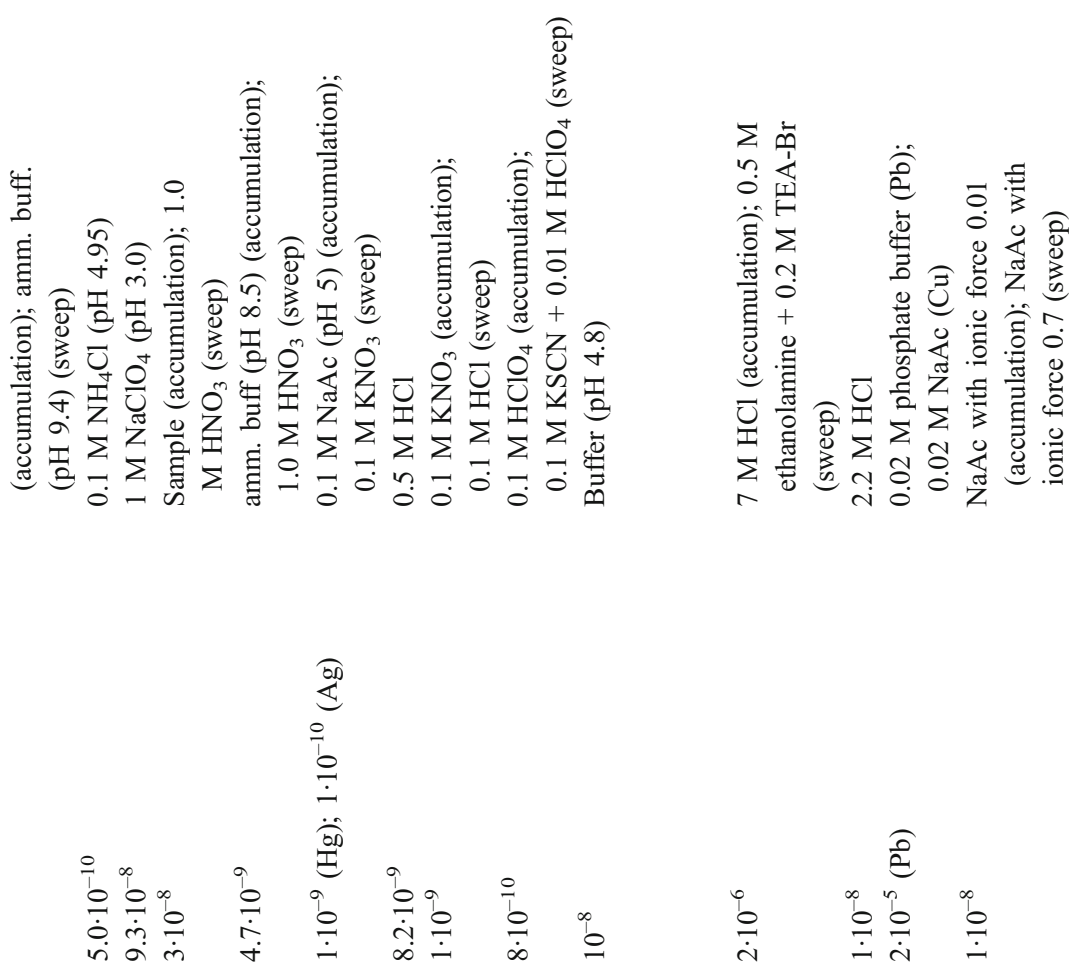

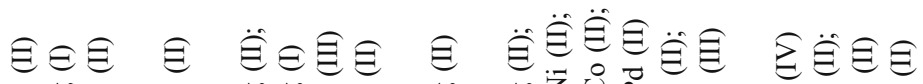

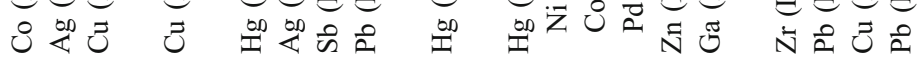

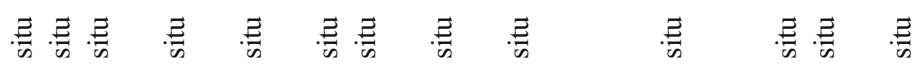

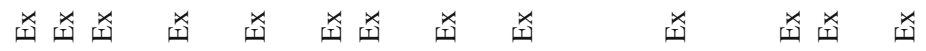

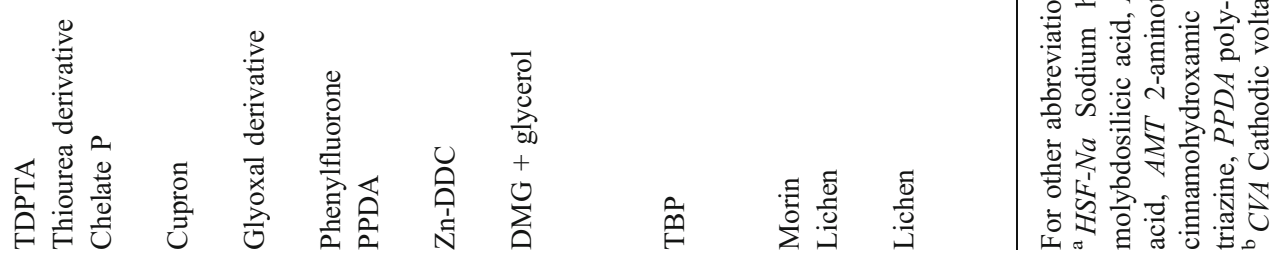


conceived because despite good performance capabilities of mercury electrodes with respect to the adsorptive concentration of inorganic ions [196-198], they have some limitations at positive potential range, while many solid electrodes, which are operable over a wide interval of potentials, cannot selectively sorb the required component of the system. Adams' idea was not overlooked by other investigators, and in 1964, Kuwana et al. performed research making the first contribution to the advancement of chemically modified carbon-paste electrodes, which are described in the reviews [199-201].

CPE is made of a homogenized paste of fine-dyspersated coal and a water-immiscible binding liquid. Paraffin, petrolatum, or polychlorotrifluoroethylene oils, silicon fluid, dioctylphthalate, $\alpha$-bromnaphthalene, tricresyl phosphate, and other materials can be used as the binding liquid. Two types of CPE pastes are available: dry $(0.3-0.5 \mathrm{ml}$ of the binding liquid per $1 \mathrm{~g}$ of the carbon powder) and wet (0.5-0.9 $\mathrm{ml}$ of the binding liquid per $1 \mathrm{~g}$ of the carbon powder) pastes. CPE can bear a high residual current caused by oxygen admixed to the paste with carbon powder particles. The residual current can be eliminated if the preheated carbon powder is mixed with wax, paraffin, or petrolatum oil in the nitrogen atmosphere or a lipophilic paste fluid (tricresyl phosphate) is added. The detection limit (LOD) of many inorganic and organic substances on CPE generally is $1 \cdot 10^{-9} \mathrm{M}$. LOD is frequently decreased by activation of the electrode at high negative or positive potentials. The anode activation of the electrode is most efficient because interfering organic substances can be removed from the surface in this case. Sometimes the electrode is "shaken up" through the cyclic polarization between large negative and positive potentials.

When compared to other carbon-containing electrodes, CPE has a well-developed surface with a high adsorptivity of various substances. This property of CPE is used successfully in voltammetry for the modification and the adsorptive accumulation of substances to be measured. A modifier can be immobilized on CPE by several means including sorption, covalent binding, dissolution of a lipophilic modifier in the paste fluid, and direct mixing with the carbon paste. Direct mixing of a modifier with the paste is used most frequently. This modification procedure is very simple: a modifier is added to the paste in the dry form or diluted in a small amount of an organic solvent making the paste more homogeneous. Other methods of the modifier immobilization are used least often. The depolarizer is concentrated on the modified CPE surface through adsorption, chemical, or electrostatic interaction of the element to be measured and the modifier. CPE is modified by various organic substances such as aromatic oxycarboxylic acids, aromatic amine and diimine compounds, azocompounds, dyes, thiocompounds, triazines, and quino- lines. In addition to the main hydrocarbon chain, molecules of these organic compounds include nitrogen, sulfur, and oxygen atoms, aromatic and aliphatic cycles containing unbound $\pi$-electrons, which can interact, on one hand, with the electrode surface and, on the other hand, with the analyte ensuring a high surface adsorption and strong binding to the substance to be determined.

Every so often, the analyte is concentrated on modified CPE with the circuit open using extraction, sorption, ion exchange, and formation of ion pairs. The measurement stage can be accomplished in another electrolyte. As the electrolyte is replaced, it is possible to optimize the measurement parameters $(\mathrm{pH}$, the ionic force, and the potential) and eliminate the interference of other components of the test solution. Dependences of the current peak of the element to be determined on the concentration and the accumulation time on CPE are flattened-out curves because all functional groups of the modifier are saturated.

Table 2 gives examples of specific applications of modified CPE for the voltammetric determination of metal ions [202-312]. Sometimes CPE is modified by films of metals and their oxides [202-213, 215-216]. The electrode is modified most frequently by crown compounds [216221], calixarenes [222], cyclodextrins [223-225], nonfunctionalized and functionalized silica [226-243], clay minerals (vermiculite and montmorillonite) [244-253], ion exchangers in the form of artificial resins [254-258 258262], natural humic acids and soils [259-263], organic [264-310], and bioactivecompounds [311-312].

Electrodes based on silica with self-organizing monolayers, for example, mesoporous silica modified by acetamide of the phosphonic acid provide accumulation and measurement of $\mathrm{Cu}, \mathrm{Pb}, \mathrm{Cd}$, and $\mathrm{U}$ [240-241]. CPE modified by biocatalysts, which are constituents of $\alpha$ - and $\beta$-cyclodextrins [223-225] or natural lichens [311-312] are used for measurement of ions of heavy metals.

Solid depolarizers can be studied after their direct infusion to CPE, which has been called the carbon-paste electroactive electrode (CPEE). The CPEE methodology was recognized to be also suitable for insoluble electroactive compounds. The first studies of metals, metal oxides, chalcogenides, salts, and other compounds by CPEE methodology were reviewed by Brainina et al. [313]. Electrochemical transformations taking place on CPEE provide information about the electrochemical activity of solid compounds, their stoichiometry, the oxidized state of elements, the morphology (the size and the shape of particles, crystal defects), the catalytic activity, etc. The CPEE methodology significantly increased the scope of electrochemistry to poorly conducting and insoluble solids. CPEE is used to analyze lead sulfides, magnetite, oxides of silver, tin, copper, and iron, bromides of rare-earth elements, nickel-containing compounds and other solids, 
e.g., ceramics and classes [314-318]. A comprehensive review [319] is dedicated to the electrochemical analysis of solids.

\section{Conclusion}

Considering the above numerous examples of the electrochemical study and determination of various elements and compounds, it can be concluded that the modification of the surface of solid electrodes by a variety of methods and substances considerably extends the capabilities of voltammetry and ensures a highly sensitive and selective determination of a wide range of elements traces.

Acknowledgements Financial support of Russian Foundation for Basic Research (project No. 07-03-96070-r_ural_a) and International Science and Technology Center (projects nos. 342, 2132 and 2897) is gratefully acknowledged.

Open Access This article is distributed under the terms of the Creative Commons Attribution Noncommercial License which permits any noncommercial use, distribution, and reproduction in any medium, provided the original author(s) and source are credited.

\section{References}

1. Maystrenko VN, Gusakov VN, Sangalov EYU (1995) J Anal Chem 50:582

2. Vjaselev MR (1995) J Anal Chem 50:723

3. Budnikov GK (1996) J Anal Chem 51:374

4. Wang J, Tian B (1999) Anal Chim Acta 385:429

5. Brainina KHZ (2001) J Anal Chem 56:344

6. Bakker E (2004) Anal Chem 76:3285

7. Bakker E, Qin Y (2006) Anal Chem 78:3965

8. Vlasov YUG (1992) J Anal Chem 47:114

9. Zolotov YUA (1990) J Anal Chem 45:1255

10. Mjasoyedov BF, Davydov AV (1990) J Anal Chem 45:1259

11. Brainina KHZ (1995) Anal Chim Acta 305:146

12. Tarasevich MR, Bogdanovskaja VA, Gegeshidze LV (1999) J Anal Chem 54:966

13. Budnikov G, Murinov Yu, Maystrenko V (1994) Voltammetry with modified and ultramicroelectrodes. Nauka, Moscow

14. Bakker E (2004) Anal Chem 76:3285

15. Bakker E, Telting-Diaz M (2002) Anal Chem 74:2781

16. Dong S, Wang Y (1989) Electroanalysis 1:99

17. Wang J (1991) Electroanalysis 3:255

18. Downard AJ (2000) Electroanalysis 12:1085

19. Walcarius A (2001) Electroanalysis 13:701

20. Navratilova Z, Kula P (2003) Electroanalysis 15:837

21. Zen JM, Kumar AS, Tsai DM (2003) Electroanalysis 15:1073

22. Yosypchuk B, Novothý L (2002) Electroanalysis 14:1733

23. Mikkelsen Ø, Schrøder KH (2003) Electroanalysis 15:679

24. McCreery RL (1999) Electrochemical properties of carbon surfaces. In: Wieckowski A (ed) Interfacial electrochemistry. Theory, experiment and applications. Dekker, New York, pp 631-647

25. Tarasevich MR (1984) Electrochemistry of carbon materials. Nauka, Moscow
26. Lisichkin GV (2003) Chemistry of graft surface compounds. Phismatlit, Moscow

27. Khanina RM, Tataurov VP, Brainina KHZ (1988) Zavodsk Lab 54/2:1

28. Kaplin AA, Pikula NP, Neyman E (1990) J Anal Chem 45:2086

29. Hardcastle JL, Murcott GG, Compton RG (2000) Electroanalysis 12:559

30. Kilimnik AB, Abakumova EA, Churikov AV (1998) Zavodsk Lab 64/4:12

31. Lowinsohn D, Bertotti M (2002) Electroanalysis 14:619

32. Viter IP, Kamenev AI (1997) J Anal Chem 52:1180

33. Fofonova TM, Bulantseva VN, Karbainov Y (1995) J Anal Chem 50:283

34. Tomcik P, Banks CE, Compton RG (2003) Electroanalysis 15:1661

35. Staden JF, Matoetoe M (1997) Fresenius J Anal Chem 357:624

36. Shiu K, Shi K (1998) Electroanalysis 10:959

37. Scholz F, Meyer S (1994) Naturwissenschaften 81:450F

38. Meyer S, Scholz F, Trittler R (1996) Fresenius J Anal Chem 356:247

39. Roitz JS, Bruland KW (1997) Anal Chim Acta 344:175

40. Zhang J, Di F (2003) Talanta 60:31

41. El-Maali NA, El-Hady DA (1998) Anal Chim Acta 370:239

42. Staden JF, Matoetoe MC (1998) Anal Chim Acta 376:325

43. Compton RG, Eclund JC, Marken F (1997) Electroanalysis 9:509

44. Nadezhina LS, Konstantinova SA, Filanovsky BK (1991) J Anal Chem 46:2442

45. Nadezhina LS, Lobnova OA, Pankina IA (1998) J Anal Chem $53: 171$

46. Zgadova VA, Nemova VV, Nemov VA (1987) J Anal Chem 62:1644

47. Fischer E, Berg CMG (1999) Anal Chim Acta 385:273

48. Wu HP (1996) Anal Chem 68:1639

49. Nesterina EM, Bebeschko GI (2002) Zavodsk Lab 68:13

50. Sun YC, Tu YL, Mierzwa J (1998) Fresenius J Anal Chem 360:550

51. Petrov SI, Ivanova ZHV (2000) J Anal Chem 55:1224

52. Petrov SI, Kukhnikova LV, Ivanova ZHV (1998) Zavodsk Lab 64/9:13

53. Petrov SI, Kukhnikova LV, Ivanova ZHV (1998) Zavodsk Lab 64/6:13

54. Silva CL, Masini JC (2000) Fresenius J Anal Chem 367:284

55. Lee JD, Lo JM (1994) Anal Chim Acta 287:259

56. Economou A, Fielden PR (1996) Analyst 121:1903

57. Ashley K (1995) Electroanalysis 7:1189

58. Laar C, Reinke L, Simon J (1994) Fresenius J Anal Chem 349:692

59. Kozina SA (2003) J Anal Chem 58:1067

60. Woolever CA, Dewald HD (2001) Electroanalysis 13:309

61. Monterroso SCC, Carapuça HM, Simão JEJ et al (2004) Anal Chim Acta 503:203

62. Wahdat F, Hinkel S, Neeb R (1995) Fresenius J Anal Chem 352:393

63. Hoyer B, Jensen N (2004) Analyst 129:751

64. Brett CMA, Brett AMO, Tugulea L (1996) Anal Chim Acta 322:151

65. Martinotti W, Queirazza G, Guarinoni A, Mori G (1995) Anal Chim Acta 305:183

66. Oliveira MF, Saczk AA, Okumura LL, Fernandes AP, Moraes M, Stradiotto NR (2004) Anal Bioanal Chem 380:135

67. Oliveira MF, Khoulif Z, Jambon C, Chatelut M (1993) Electroanalysis 5:339

68. Daniel L, Zakharova EA, Goloskova NB, Schelkovnikova VV (1992) J Anal Chem 47:448

69. Lange B, Scholz F (1997) Fresenius J Anal Chem 358:736 
70. Adeloji SBO, Pablo F (1995) Electroanalysis 7:476

71. Rocha MM, Neto MM, Yorres MO, Varennes A (1997) Electroanalysis 9:145

72. Turyan I, Mandler D (1994) Anal Chem 66:58

73. Adeloju SBO, Pablo F (1992) Anal Chim Acta 270:143

74. Adeloju SBO, Pablo F (1995) Electroanalysis 7:750

75. Sanchez-Misiego A, Garcia-Moncó Carra R, Zirino A (1996) Electroanalysis 8:534

76. Diederich H, Meyer S, Scholz F (1994) Fresenius J Anal Chem 349:670

77. Geary CD, Weber SG (2003) Anal Chem 75:6560

78. Brett CMA, Brett AMO, Pereira JLC (1991) Electroanalysis 3:683

79. Brett CMA, Brett AMO, Tugulea L (1996) Electroanalysis 8:639

80. Economou A, Fielden PR (1993) Anal Chim Acta 273:27

81. Rasul SB, Munir AKM, Hossain ZA et al (2002) Talanta 58:33

82. Dai X, Nekrassova O, Hyde ME, Compton RG (2004) Anal Chem 76:5924

83. Korolczuk M (1996) Fresenius J Anal Chem 356:480

84. Ireland-Ripert J, Bermond A, Ducauze C (1982) Anal Chim Acta 143:249

85. Hamlton TW, Ellis J (1979) Anal Chim Acta 110:87

86. Zen IJ, Chung MJ (1995) Anal Chem 67:3571

87. Viter IP, Kamenev AI (1993) J Anal Chem 48:1197

88. Fijatek Z, Łozak A, Sarna K (1998) Electroanalysis 10:846

89. Korolczuk M, Tyszczuk K, Grabarczyk M (2005) Electrochem commun 7:1185

90. Dai X, Compton RG (2006) Analyst 131:516

91. Charalambous A, Economou A (2005) Anal Chim Acta 547:53

92. Kefala G, Economou A, Voulgaropoulos A, Sofoniou M (2003) Talanta 61:603

93. Prior C, Lenehan CE, Walker GS (2006) Electroanalysis 18:2486

94. Boteelho CMS, Boaventura RAR, Goncalves MLS (2002) Electroanalysis $14: 1713$

95. Banks CE, Kruusma J, Hyde ME et al (2004) Anal Bioanal Chem 379:277

96. Wang J, Lu J, Kirgöz ÜA et al (2001) Anal Chim Acta 434:29

97. Wang J, Lu D, Hongngamdee S, Lin Y et al (2006) Talanta 69:914

98. Krolicka A, Bobrowski A, Kalcher K et al (2003) Electroanalysis $15: 1859$

99. Korolczuk M, Moroziewicz A, Grabarczyk M (2005) Anal Bional Chem 382:1678

100. Chatzitheodorou E, Economou A, Voulgaropoulos A (2004) Electroanalysis $16: 1745$

101. Bobrowski A, Nowak K, Zarebski J (2005) Anal Bional Chem 382:1691

102. Lin L, Lawrence N, Thongngamdee S et al (2005) Talanta 65:144

103. Morfobos M, Economou A, Voulgaropoulos A (2004) Anal Chim Acta 519:57

104. Wang J, Thongngamdee S, Lu D (2006) Electroanalysis 18:59

105. Kefala G, Economou A, Voulgaropoulos A (2006) Electroanalysis $18: 223$

106. Grabarczyk M, Tyszczuk K, Korolczuk M (2006) Electroanalysis 18:70

107. Yang Z, Alafandy M, Boutakhrit K et al (1996) Electroanalysis $8: 25$

108. El-Maali NA, El-Hady DA (1999) Electroanalysis 11:201

109. El-Maali NA, El-Hady DA, El-Hamid AM, Seliem MM (2000) Anal Chim Acta 417:65

110. Di J, Zhang F, Zhang M, Bi S (2004) Electroanalysis $16: 644$

111. Guo SH, Khoo SB (1999) Electroanalysis 11:891

112. Turyan I, Mandler D (1994) Fresenius J Anal Chem 349:491

113. $\mathrm{Hu} \mathrm{S}, \mathrm{Wu} \mathrm{K}, \mathrm{Yi} \mathrm{H}$ et al (2001) Fresenius J Anal Chem 370:101
114. Shiu KK, Song FY (1998) Elecrtoanalysis 10:256

115. Komura T, Isogai S, Yamaguchi $\mathrm{T}$ et al (2000) J Electroanal Chem 490:70

116. Li Q, Bi S, Ji G (2003) J Electroanal Chem 560:19

117. Huang W, Zhang S (2002) Anal Sci 18:187

118. Zbou Y, Zbu G, Wang E (1994) Electroanalysis 6:903

119. Wagner K, Strojek JW, Koziel K (2001) Anal Chim Acta 447:11

120. García CD, Ortiz PI (2003) Talanta 61:547

121. Khoo SB, Zhu J (1999) Electroanalysis 11:546

122. Turyan I, Mandler D (1994) Electroanalysis 6:838

123. Turyan I, Mandler D (1993) Nature. Scientific correspondence $362: 703$

124. Lu J, He X, Zeng X et al (2003) Talanta 59:553

125. Zheng H, Dong H, Yan $Z$ et al (2006) Electroanalysis 18:2115

126. Zheng H, Yan Z, Dong H, Ye B (2007) Sens Actuators B: Chemical 120:603

127. Crowley K, Cassidy J (2002) Electroanalysis 14:1077

128. Yang S, Tian H, Wang D, Tang Y (1995) J Electroanal Chem $383: 31$

129. Moretto LM, Ugo P, Lacasse R et al (1999) Electrochemical Society Proceedings. Proceedings of the symposium on "Chemical and biological sensors and analytical electrochemical methods" 97:255

130. Ugo P, Moretto LM, Rudello A et al (2001) Electroanalysis 13:661

131. Ugo P, Moretto LM, Boni AD et al (2002) Anal Chim Acta 474:147

132. Kruusma J, Nei L, Hardcastle JL et al (2004) Electroanalysis $16: 399$

133. Gutierrez CA, Hardcastle JL, Ball JC, Compton RG (1999) Analyst 124:1053

134. Hurst MP, Bruland KW (2005) Anal Chim Acta 546:68

135. Dam MER, Scroder KH (1996) Electroanalysis 8:1040

136. Capelo S, Mota AM, Gonçalves MLS (1995) Electroanalysis 7:563

137. West CE, Hardcastle JL, Compton RG (2002) Electroanalysis $14: 1470$

138. Brett CMA, Brett AMO, Matysik FM et al (1996) Talanta 43:2015

139. Matysik FM, Matysik S, Brett AMO, Brett CMA (1997) Anal Chem 69:1651

140. Brett CMA, Alves VA, Fungaro DA (2001) Electroanalysis $13: 212$

141. Lam MT, Chakrabarti CL, Cheng J, Pavski V (1997) Electroanalysis $9: 1018$

142. Dalangin RR, Gunasingham H (1994) Anal Chim Acta 291:81

143. Murimboh J, Lam MT, Hassan NM, Chakrabarti CL (2000) Anal Chim Acta 423:115

144. Buckova M, Vanickova M, Labuda J (1996) Chem Papers $50: 279$

145. Zen JM, Ting YS (1996) Anal Chim Acta 332:59

146. Wang J, Deo RP, Thongngamdee S, Ogorevc B (2001) Electroanalysis 13:1153

147. Kefala G, Economou A, Voulgaropoulos A (2004) Analyst 129:1082

148. Merkoçi A, Vasjari M, Fabregas E et al (2000) Microchim Acta 135:29

149. Turyan I, Atiya M, Mandler D (2001) Electroanalysis 13:653

150. Chen Z, Pourabedi Z, Hibbert DB (1999) Electroanalysis 11:964

151. Li NB, Luo HQ, Chen GN (2004) Anal sci 20:825

152. Zen JM, Huang SY (1994) Anal Chim Acta 296:77

153. Yang HY, Sun IW (2000) Electroanalysis 12:1476

154. Yang HY, Sun IW (1998) Anal Chim Acta 358:285

155. Zen JM, Hsu FS, Chi NY et al (1995) Anal Chim Acta 310:407

156. Zen JM, Lin HY, Yang HH (2001) Electroanalysis 13:505

157. Ugo P, Moretto LM, Mazzocchi GA (1993) Anal Chim Acta 273:229 
158. Ugo P, Moretto LM, Mazzocchi GA (1995) Anal Chim Acta 305:74

159. Ugo P, Zampieri S, Moretto LM, Paolucci D (2001) Anal Chim Acta 434:291

160. Yang HY, Chen WY, Sun IW (1999) Talanta 50:977

161. Lu TH, Sun IW (1998) Electroanalysis 10:1052

162. Lu TH, Huang JF, Sun IW (2002) Anal Chim Acta 454:93

163. Yang HY, Sun IW (2000) Anal Chem $72: 3476$

164. Yang HY, Sun IW (1999) Electroanalysis 11:195

165. Khoo SB, Zhu J (1998) Anal Chim Acta 373:15

166. Ugo P, Sperni L, Moretto LM (1997) Electroanalysis 9:1153

167. Arrigan DWM, Lowens MJ (1999) Electroanalysis 11:647

168. Yang N, Wan Q, Yu J (2005) Sens Actuators B 110:246

169. Hoyer B, Sørensen G, Jensen N et al (1996) Anal Chem 68:3840

170. Hoyer B, Sørensen G, Jensen N, Christensen MK (1999) Electroanalysis 11:940

171. Zen JM, Wang HF, Kumar AS et al (2002) Electroanalysis 14:99

172. Shpigun LK, Lunina VK (2003) J Anal Chem 58:1200

173. Shpigun LK, Lunina VK (2003) J Anal Chem 58:1097

174. Rahman MA, Won MS, Shim YB (2003) Anal Chem 75:1123

175. Rahman MA, Park DS, Won MS et al (2004) Electroanalysis $16: 1366$

176. Turyan I, Erichsen T, Schuhmann W et al (2001) Electroanalysis 13:79

177. Zen JM, Wu JW (1996) Anal Chem 68:3966

178. Zen JM, Wu JW (1997) Electroanalysis 9:302

179. Christensen MK, Hoyer B (2000) Electroanalysis 12:35

180. Tsai YC, Davis J, Compton RG et al (2001) Electroanalysis 13:7

181. Brett CMA, Fungaro DA (2000) Talanta 50:1223

182. Monterroso SCC, Carapuca HM, Duarte AC (2003) Electroanalysis $15: 1878$

183. Mogensen L, Kryger L (1998) Electroanalysis 10:1285

184. Monterroso SCC, Carapuça HM, Duarte AC (2005) Talanta 65:644

185. Monterroso SCC, Carapuça HM, Duarte AC (2006) Talanta 68:1655

186. Lack B, Duncan J, Nyokong T (1999) Anal Chim Acta 385:393

187. Yi H (2003) Anal Bioanal Chem 377:770

188. Wu K, Hu S, Fei J et al (2003) Anal Chim Acta 489:215

189. Sun D, Xie X, Cai Y et al (2007) Anal Chim Acta 581:27

190. Gregory XD, Wildgoose G, Compton RG (2006) Analyst 131:1241

191. Economou A, Fielden PR (2003) Analyst 128:205

192. Ivaska A (1991) Electroanalysis 3:247

193. Mandler D, Turyan I (1996) Electroanalysis 8:207

194. Gooding J, Mearns F, Yang W et al (2003) Electroanalysis 15:81

195. Petrovic SC, Dewald HD (1997) Anal Chim Acta 357:33

196. Paneli MG, Voulgaropoulos A (1993) Electroanalysis 5:355

197. Abu Zuhri AZ, Voelter W (1998) Fresenius J Anal Chem 360:1

198. Zaitsev PM, Salikhdzhanova RF, Zaitsev NK (1999) Zavodsk Lab 65/1:3

199. Kalcher K (1990) Electroanalysis 2:419

200. Ulakhovich NA, Medjantseva EP, Budnikov GK (1993) J Anal Chem 48:980

201. Kalcher K, Kauffmann JM, Wang J et al (1995) Electroanalysis 7:5

202. Simm AO, Banks CE, Wilkins SJ et al (2005) Anal Bioanal Chem 381:979

203. Majid E, Hrapovic S, Liu Y et al (2006) Anal Chem 78:762

204. Švancara I, Vytras K, Bobrowski A, Kalcher K (2002) Talanta $58: 45$

205. Gevorgjan AM, Vanukov VV, Vaznenko SV (2002) J Anal Chem $57: 301$

206. Švancara I, Matoušek M, Sikora E et al (1997) Electroanalysis 9:827

207. Flechsig GU, Korbout O, Hocevar SB et al (2002) Electroanalysis 14:192
208. Hočevar S, Švancara I, Vytřas K et al (2005) Electrochim Acta $51: 706$

209. Švancara I, Baldrianova L, Tesařova E et al (2006) Electroanalysis 18:177

210. Krolicka A, Pauliukaite R, Ŝvancara I et al (2002) Electrochem Commun 4:193

211. Pauliukaite R, Metelka R, Švancara I et al (2002) Anal Bioanal Chem 374:1155

212. Švancara I, Pravda M, Hvizdalova M et al (1994) Electroanalysis 6:663

213. Sherigara BS, Shivaraj Y, Mascarenhas RJ et al (2007) Electrochim Acta 52:3137

214. Mascarenhasa RJ, Satpati AK, Yellappa S et al (2006) Anal Sci 22:871

215. Yoon JH, Muthuraman G, Yang JE et al (2007) Electroanalysis 19:1160

216. Shaydarova LG, Ulakhovich NA, El-Gakhri MA et al (1995) J Anal Chem 50:755

217. Ulakhovich NA, El-Gakhri MA, Shaydarova LG et al (1994) Zavodsk Lab 60/3:14

218. Shaydarova LG, Ulakhovich NA, Fedorova IL et al (1996) J Anal Chem 51:746

219. Shaydarova LG, El-Gakhri MA, Ulakhovich NA et al (1994) J Anal Chem 49:501

220. Ijeri VS, Srivastava AK (2000) Fresenius J Anal Chem 367:373

221. Tanaka S, Yoshida H (1989) Talanta 36:1044

222. Canpolat EÇ, Şar E, Coşkun NY et al (2007) Electroanalysis 19:1109

223. Roa-Morales G, Ramírez-Silva MT, González RL et al (2005) Electroanalysis 17:694

224. Roa-Morales G, Ramírez-Silva MT, Romero-Romo MA et al (2003) Anal Bioanal Chem 377:763

225. Roa-Morales G, Ramírez-Silva MT, González RL et al (2003) J of Solid State Electrochemistry 7:355

226. Alpat SK, Yuksel U, Akcay H (2005) Electrochem commun $7: 130$

227. Walcarius A, Mariaulle P, Lamberts L (2003) J of Solid State Electrochemistry 7:671

228. Walkarius A, Despas C, Bessiere J (1999) Anal Chim Acta 385:79

229. Walkarius A, Bessiere J (1997) Electroanalysis 9:707

230. Walcarius A, Devoy J, Bessiere J (2000) J. of Solid State Electrochemistry 4:1433

231. Etienne M, Bessiere J, Walcarius A (2001) Sens Actuators 76:531

232. Filho NLD, Carmo DR, Rosa AH (2006) Electrochim Acta 52:965

233. Takeuchi RM, Santos A, Padilha PM et al (2007) Talanta 71:771

234. Takeuchi RM, Santos A, Padilha PM et al (2007) Anal Chim Acta 584:295

235. Marino G, Bergamini MF, Teixeira MS et al (2003) Talanta 59:1021

236. Aleixo LM, Souza MFB, Godinho OES et al (1993) Anal Chim Acta 271:143

237. Filho NLD, Carmo DR, Caetano L et al (2005) Anal Sci 21:1359

238. Yantasee W, Lin Y, Zemanian TS et al (2003) Analyst 128:467

239. Sayen S, Etienne M, Bessiere J et al (2002) Electroanalysis 14:1521

240. Yantasee W, Lin Y, Fryxell GE et al (2004) Electroanalysis $16: 870$

241. Yantasee W, Lin Y, Fryxell GE et al (2004) Anal Chim Acta 502:207

242. Bond AM, Miao W, Smith TD et al (1999) Anal Chim Acta 396:203

243. Shams E, Torabi R (2006) Sens Actuators B 117:86

244. Ogorevc B, Cai X, Grabec I (1995) Anal Chim Acta 305:176

245. Svegl IG, Ogorevc B, Hudnik V (1996) Fresenius J Anal Chem 354:770 
246. Kalcher K, Grabec I, Raber G et al (1995) J Electroanal Chem 386:149

247. Švegl IG, Kolar M, Ogorevc B et al (1998) Fresenius J Anal Chem 361:358

248. Kula P, Navratilova Z (1996) Fresenius J Anal Chem 354:692

249. Huang W (2004) Microchim Acta 144:125

250. Huang W, Yang C, Zhang S (2002) Anal Bioanal Chem 374:998

251. Kula P, Navratilova Z, Kulova P et al (1999) Anal Chim Acta 385:91

252. Wang J, Martinez T (1989) Electroanalysis 1:167

253. Filho NLD, Carmo DRC, Gessner F et al (2005) Anal sci 21:1309

254. Wang J, Greene B, Morgan C (1984) Anal Chim Acta 158:15

255. Labuda J, Korgová H, Vaníčková M (1995) Anal Chim Acta 305:42

256. Agraz R, Sevilla MT, Pinilla JM et al (1991) Electroanalysis 3:393

257. Agraz R, Sevilia MT, Hernandez L (1995) J Electroanalytical Chemistry 390:47

258. Helms I, Scholz F (1996) Fresenius J Anal Chem 356:237

259. Sun Q, Wang C, Li L et al (1999) Fresenius J Anal Chem 363:114

260. Jeong ED, Won MS, Sbim YB (1994) Electroanalysis 6:887

261. Wang C, Zhang H, Sun Y et al (1998) Anal Chim Acta 361:133

262. Wang C, Li H (1998) Electroanalysis 10:44

263. Švegl IG, Ogorevc B (2000) Fresenius J Anal Chem 367:701

264. Švancara I, Kalcher K, Diewald W et al (1996) Electroanalysis $8: 336$

265. Lubert KH, Beyer L, Casabo J et al (1998) Electroanalysis $10: 860$

266. Guo H, Li Y, Xiao P et al (2005) Anal Chim Acta 534:143

267. Liu N, Song JF (2005) Anal Bioanal Chem 383:358

268. Ju-nan L, Jun Z, Pei-hong D et al (2001) Analyst 126:2032

269. Liu S, Li J, Zhang S et al (2005) Applied Surface Science 252:2078

270. Stadlober M, Kalcher K, Raber G (1997) Sci Pap Univ Pardubice Ser A 3:103

271. Stadlober M, Kalcher K, Raber G (1997) Anal Chim Acta 350:319

272. Švancara I, Galik M, Vytras K (2006) Talanta 72:512

273. Galik M, cholota M, Švancara I et al (2006) Electroanalysis 18:2218

274. Bai ZP, Nakamura T, Izutsu K (1990) Electroanalysis 2:75

275. Ferri T, Guidi F, Morabito R (1994) Electroanalysis 6:1087

276. Raber G, Kalcher K, Neuhold CG et al (1995) Electroanalysis $7: 138$

277. Gurentsova OI, Prokhorova GV, Osipova EA (1992) J Anal Chem 47:1671

278. Prokhorova GV, Osipova EA, Gurentsova OI (1993) J Anal Chem 48:1621

279. Osipova EA, Prokhorova GV, Gurentsova OI (1994) Zavodsk Lab 60/2:5

280. Osipova EA, Kamenev AI, Sladkov VE et al (1997) J Anal Chem 52:273

281. Osipova EA, Sladkov VE, Kamenev AI et al (2000) Anal Chim Acta 404:231

282. Osipova EA, Sladkov VE, Shkinev VM (2000) J Anal Chem $55: 844$
283. Sladkov VE, Osipova EA (2001) J Anal Chem $56: 52$

284. Yabutani T, Utsunomiya Y, Kado Y et al (2006) Anal sci 22:1021

285. Cai Q, Khoo SB (1995) Electroanalysis 7:379

286. Khoo SB, Guo SX (1999) J Electroanal Chem 465:102

287. Khodari M, Krisha MMA, Fandy R (1994) Talanta 41:2179

288. Fanta K, Chandravanshi BS (2001) Electroanalysis 13:484

289. Degefa TH, Chandravanshi BS, Alemu H (1999) Electroanalysis $11: 1305$

290. Refera T, Chandravanshi BS, Alemu H (1998) Electroanalysis 10:1038

291. Molina-Holgado T, Pinilla-Macias JM, Hernandez-Hernandez L (1995) Anal Chim Acta 309:117

292. Ruiperez J, Mendiola MA, Sevilla MT et al (2002) Electroanalysis 14:532

293. Colilla M, Mendiola MA, Procopio JR et al (2005) Electroanalysis 17:933

294. Hernandez E, Naranjo-Rodriguez I, Hidalgo-Hidalgo de Cisneros JL (2007) Sens Actuators B 123:488

295. Navratilova Z (1991) Electroanalysis 3:799

296. Prabhu SV, Baldwin RP (1987) Anal Chem 59:1074

297. Gao Z, Li P, Wang G et al (1990) Anal Chim Acta 241:137

298. Hu C, Wu K, Dai X et al (2003) Talanta 60:17

299. Khoo SB, Soh MK, Cai Q et al (1997) Electroanalysis 9:45

300. Lu X, Wang Z, Geng Z et al (2000) Talanta 52:411

301. Guttman M, Beyer KHL (1996) Fresenius J Anal Chem 356:263

302. Agraz R, Miguel J, Sevilla MT et al (1996) Electroanalysis 8:565

303. Peng T, Shen L, Wang G (1996) Microchimica Acta 122:125

304. Woon MS, Moon DW, Shim YB (1995) Electroanalysis 7:1171

305. Khoo SB, Zhu J (1996) Analyst 121:1983

306. Adraoui I, Rhazi ME, Amine A et al (2005) Electroanalysis 17:685

307. Khoo SB, Cai Q (1996) Electroanalysis 8:549

308. Zhang ZQ, Liu H, Zhang $H$ et al (1996) Anal Chim Acta 333:119

309. Kurbatov DI, Bulgakova L (1996) J Anal Chem 51:410

310. Liu S, Li J, Mao X (2003) Electroanalysis 15:1751

311. Connor M, Dempsey E, Smytb MR et al (1991) Electroanalysis $3: 331$

312. Ramos JA, Bermejo E, Zapardiel A et al (1993) Anal Chim Acta 273:219

313. Brainina Kh, Neyman E (1993) Electroanalytical stripping methods. Wiley, New York

314. Brainina Kh, Khodos M, Belisheva G, Vidrevich M (1990) Zeitschrift Fur Physikalischr Chemie Neue Folge 168:65

315. Gruner W, Stablberg R, Brainina Kh, Akselrod N, Kamyshov V (1990) Electroanalysis 2:397

316. Ulakhovich NA, Medjantseva EP, Mashkina SV (1997) J Anal Chem 52:373

317. Domenech-Carbo A, Domenech-Carbo MT, Gimeno-Adelantado JV et al (2000) Electroanalysis 12:120

318. Fetisov VB, Ermakov AN, Belysheva GM, Fetisov AV, Kamyshov VM, Brainina KHZ (2004) J Solid State Electrochem 8:565

319. Grygar T, Marken F, Schröder U, Scholz F (2002) Collect Czech Chem Commun 67:163 